MATL INST OF STANDARDS \& TECH R.I.C

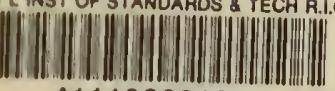

A1 1102621983

Cellanan, Jane E/Revlew of needs tor the OC 100 . U56 NO.87-3064 1987 V19 C.1 NBS-P

NBS

7 PUBLICATIONS

REVIEW OF NEEDS FOR

THERMOPHYSICAL PROPERTY DATA ON SOLID FEEDSTOCKS

II. Oil Shale

Jane E. Callanan

National Bureau of Standards

U.S. Department of Commerce

Boulder, Colorado 80303-3328

April 1987

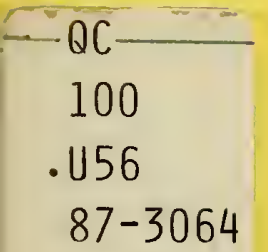





\section{REVIEW OF NEEDS FOR \\ THERMOPHYSICAL PROPERTY DATA ON SOLID FEEDSTOCKS \\ II. Oil Shale}

Jane E. Callanan

Chemical Engineering Science Division

Center for Chemical Engineering

National Engineering Laboratory

National Bureau of Standards

Boulder, Colorado 80303-3328

April 1987

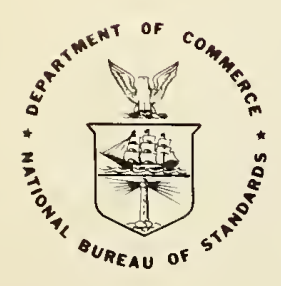

U.S. DEPARTMENT OF COMMERCE, Malcolm Baldrige, Secretary 



\section{CONTENTS}

LIST OF TABLES . . . . . . . . . . . . . . . . . . . . . v v

LIST OF FIGURES. . . . . . . . . . . . . . . . . . . . . . v v

ABSTRACT . . . . . . . . . . . . . . . . . . vii

1. INTRODUCTION . . . . . . . . . . . . . . . . . . . 1

2. NATURE AND EXTENT OF THE RESOURCE. . . . . . . . . . . . 1

2.1 Nature of Oil Shale . . . . . . . . . . . . . . . . . . 1

2.2 Extent of the Shale Resource. . . . . . . . . . . 3

2.3 Eastern and Western Shales. . . . . . . . . . . 4

3. CHARACTERIZATION AND ANALYSIS. . . . . . . . . . . 5

3.1 Characterization. . . . . . . . . . . . . . 5

3.2 Analysis. . . . . . . . . . . . . . . . 5

3.2.1 Mineral. . . . . . . . . . . . . . . 5

3.2.2 0il yield. . . . . . . . . . . . . . . . 6

3.2.3 Organic. . . . . . . . . . . . . . . 8

3.2.4 Thermal analysis... . . . . . . . . . 8

3.2.5 Electromagnetic. . . . . . . . . . . . . 9

4. THERMAL PROPERTIES . . . . . . . . . . . . . . . . . . . . . 9

4.1 General Considerations. . . . . . . . . . . . . . . . . 9 9

4.2 Thermal Analysis. . . . . . . . . . . . . . . . 11

4.3 Status of Individual Thermal Properties . . . . . . . . 11

4.3.1 Heat (energy) of combustion. . . . . . . . . . . 11

4.3.2 Heat of retorting. . . . . . . . . . . . . . . . 14

4.3.3 Specific heat. . . . . . . . . . . . . . 15

4.3.4 Thermal conductivity . . . . . . . . . . 16

4.3.5 Thermal expansion. . . . . . . . . . . . . . . 17

4.3.6 Heat of immersion. . . . . . . . . . . . . . . . 17

4.4 Postscript. . . . . . . . . . . . . . . 18

5. PROCESSING AND BENEFICIATION . . . . . . . . . . . 18

5.1 History of Commercial Production. . . . . . . . . . . . 18

5.2 Oil Shale Processing. . . . . . . . . . . . . 18

5.2.1 Above ground . . . . . . . . . . . . 19

5.2.2 In situ. . . . . . . . . . . . . 19

5.2.3 Modified in situ . . . . . . . . . . . . 21

5.2.4 Developing processes............ . . 21

5.3 Beneficiation . . . . . . . . . . . . . 22 
6. KINETICS AND MODELING. . . . . . . . . . . . . 25

6.1 General Considerations. . . . . . . . . . . . . . 25

6.2 Kinetics. . . . . . . . . . . . . . . . . . 25

6.3 Modeling. . . . . . . . . . . . . . . . 27

7. RECOMMENDATIONS. . . . . . . . . . . . . . . . . 28

7.1 General Recommendations . . . . . . . . . . . . . 28

7.2 Specific Recommendations. . . . . . . . . . . . 30

8. REFERENCES . . . . . . . . . . . . . . . . . . . . . 32 


\section{LIST OF TABLES}

Table

1. Summary of consultations: oil shale. . . . . . . . . . 46

2. Estimate of world-wide shale resources. . . . . . . . . 47

3. Oil shale resources of the United States. . . . . . . . 48

4. Estimate of abundance of eastern shales by hydroassay . . 49

5. Organic and mineral constituents of eastern shale and western shales. . . . . . . . . . . . . . 50

\section{LIST OF FIGURES}

Figure

1. Van Krevelen diagram for oil shale kerogens. . . . . . . . . 51

2. Known world reserves of recoverable oil shale. . . . . . . 52

3. Major shale-bearing areas of the United States . . . . . . 53

4. Green River shale deposits . . . . . . . . . . . . . 54 



\author{
Review of Needs for Thermophysical Property Data on \\ Solid Feedstocks. II. Oil Shale \\ Jane E. Callanan \\ Thermophysical Properties Division \\ National Bureau of Standards \\ Boulder, Colorado
}

This report, a comprehensive survey concerning oil shale, is the second in a series dealing with needs, particularly for thermophysical properties, for solid fuels/feedstocks. This survey shows the need for experimental work on heat of combustion, heat of retorting, heat capacity/enthalpy, thermal conductivity, thermal expansion and heat of immersion for raw, spent and burnt shale, for kerogen and for the mineral matter found in shale. These studies should be preceded by agreement on the properties necessary for good characterization of the shale and on the methods of measuring these properties; the thermal properties measurements should be made on well-characterized samples. Standardized measurement techniques do not exist for thermal properties, with the possible exception of heat of combustion, and must be developed. Existing data must be evaluated and reliable data generated. Theoretical studies that will allow for modeling of thermal properties should proceed along with the experimental investigations to improve the ability to predict shale properties for process design. Recommendations for work appropriate to the National Bureau of Standards are included.

Key words: enthalpy; heat capacity; heat of combustion; heat of immersion; heat of retorting; oll shale; review; solid fuels feedstocks; thermal conductivity; thermal expansion. 



\section{INTRODUCTION}

This is the second of a series of reports on the needs for thermophysical property data for solid fuels/feedstocks. This report on oil shale, like the first on coal [1], is based on an extensive survey of existing literature and discussions with scientists and engineers working with shale. Table 1 lists those we have visited or contacted by telephone. This report is written against a backdrop of several years of experience with thermophysical property measurements on solid fuels/feedstocks, both coal and gas hydrates.

This report differs from the coal report in the amount of material included that is seemingly unrelated to thermophysical properties or the modeling of these properties. To some extent the inclusion of this material reflects the author's own learning process. To properly evaluate needs, it is necessary to be thoroughly familiar with the material under study. Second, shale is a less well-known material in general than coal; some material is included for the convenience of the reader.

Considerable detail is included in the section on characterization and analysis because one of the obstacles to the development of models is the lack of a coherent body of data on which to base predictions. Data on oil shale exist, but the lack of characterization information limits its usefulness. Material on analytical procedures is included to assist in judgments regarding suitable characterization information. Information on processing is included because of its bearing on measurement needs. However, neither of these two sections is meant to be an exhaustive treatment; references are representative.

In contrast, the section on thermal properties is exhaustive. Every reference available to us has been examined and evaluated. References available related to modeling have been reviewed carefully. None deal with properties modeling. References to kinetic and process models are selective.

The report outlines the nature of oil shale and the extent of the resource. After consideration of characterization, the status of thermal property information is detailed. A survey of processing methods used with oil shale, the status of beneficiation, oil shale modeling, and kinetic studies are discussed. Finally, recommendations are made both for potential studies for shale in general and, more specifically, for studies appropriate to the charter of the National Bureau of Standards (NBS).

\section{NATURE AND EXTENT OF THE RESOURCE}

\subsection{Nature of 0il Shale}

Oil shale can best be defined as any rock that yields commercial quantities of oil on destructive distillation. The oil occurs within the rock as a resinous solid, not in liquid form. The rock in which the oil occurs is not geologically a shale but rather a marlstone. The relative amounts of organic 
and mineral species in shale are variable, with mineral predominating. Rarely is the organic content greater than 20 percent. The more usual proportions for United States shales are 14-16 percent organic to 86-84 percent mineral. It is the high proportion of mineral matter that presents difficulties in processing. If the oil shale is heated without first reducing the mineral content, a great deal of energy is expended in heating a material that will not produce oil or gas.

The organic matter in oil shale is classified either as bitumen or kerogen. Bitumen is a general name for solid and semi-solid hydrocarbons that are fusible and soluble in organic solvents like carbon disulfide, asphalts, and natural mineral waxes. In many United States shales, about 10 percent of the organic matter is bitumen; the balance is kerogen. Kerogen has long been considered to be a heteroatomic polymer with a molar mass greater than 3000 [2]. Cross-linking by oxygen and sulfur leads to a three-dimensional molecular structure throughout. It is a rubbery organic material that is insoluble in most organic solvents. The organic material, like that found in petroleum source rocks, has a high hydrogen content compared to coal [3]. It is fine-grained, much of it from algal sources, and embedded in the mineral matrix. Both kerogen and bitumen are thermally unstable and begin to decompose at about $525 \mathrm{~K}$. Oil shale does not show the very short-range heterogeneity that coal does, especially within horizontal layers, because it has deposited from sediments or silt in a body of water. Regions of latitudinal character that are more or less set off from surrounding regions by some distinctive characteristic are referred to as zones.

The characterization of kerogen as a polymer has been challenged in recent years. McKay [4] describes kerogen as merely a complex hydrocarbon, of average molecular mass 600-800, that breaks down on heating.

Three types of kerogen are recognized [5-7]. Distinctions among the classes are based on the environment from which the deposition took place, the origin of the kerogen, the $\mathrm{H} / \mathrm{C}$ and $\mathrm{O} / \mathrm{C}$ ratios, the extent of maturation, and certain structural features. In type I kerogen, the organic material has deposited from a marine or a lacustrine environment, is principally of algal origin, has high $\mathrm{H} / \mathrm{C}$ to $\mathrm{O} / \mathrm{C}$ ratios, and has a highly amorphous structure. Type II kerogen has both terrestrial and marine material with marine tending to predominate. The $\mathrm{H} / \mathrm{C}$ ratio is lower than that found in type $\mathrm{I}$, the $\mathrm{O} / \mathrm{C}$ ratio higher. Aromatics and naphthene are dominant hydrocarbons; exinous, vitrinous, and fusinous materials are more common than in amorphous kerogens. Type III kerogen is mainly of terrestrial origin, has lower H/C and higher O/C ratios than the other types, has more vitrinite and fusinite than exinite or amorphous material, and has increased proportions of polycyclic aromatics and heteroatoms. Oil shales with type III kerogen are often referred to as coaly since their origins are similar to that of coal. Oil shales in which types I and II kerogen predominate produce oil; long chain aliphatics are abundant. Shales with type III kerogen produce significant quantities of gas in addition to oil. Amorphous material and algal kerogen are usually associated with high oil yields. Figure 1 shows a van Krevelen diagram (H/C vs. O/C) for shale kerogens. Kerogens are also classified as to maturity. A mature deposit is found at greater depth, has undergone thermal evolution, and produces more oil per mass percent of organic material. 
Shales of marine origin have high concentrations of silicaceous minerals and less clay-like material. In lacustrine shales, carbonates and clays predominate. The specific mineral content will vary with geographic region and with the geologic era in which deposition occurred. In some instances, a particular mineral depositional layer is so distinctive that it serves as a marker throughout the entire deposit. The well-known Mahogany marker, which locates the Mahogany zone in the Green River formation, is in fact a deposit of buff-colored carbonaceous mineral which extends very uniformly through the entire zone [8]. The mineral matter in shale is finely divided and dispersed in an organic matrix. In turn, the organic material is considered to be embedded in the mineral matrix. Whichever way it is expressed, the two species are intimately mixed, partially because of the fineness of the deposit, and very hard to separate completely, particularly by the physical means used in beneficiation processes. Jeong and Kobylinski report that little mineral matter is encapsulated by kerogen, but that over 27 percent of the bitumen is trapped by fine-grained carbonate and silicate minerals [9]. Espitalie has compared kerogen with rock containing organic matter and concludes that the heavy hydrocarbons are retained on the mineral surface [10].

The mineral matter in shale can be considered detrimental because it cannot generate hydrocarbons and it intensifies problems associated with leaching and subsequent pollution of ground waters. However, some mineral species actually exert a beneficial catalytic effect in processing. In addition, the mineral species often give rise to valuable inorganics which are commercially profitable and thus contribute to the economic feasibility of the resource.

\subsection{Extent of the Shale Resource}

Oil shale is found on all continents, but, as with other fossil fuels, is more abundant in some locations than others. The global data are incomplete because many countries, particularly those in South America, Africa, and Asia, have done little in the way of exploration or characterization of the extent and quality of the resource. In addition, there is a lack of worldwide uniformity in reporting shale grades. Figure 2 dramatically illustrates oil shale abundance throughout the world [11].

Table 2 (which has been adapted from the data of Duncan and Swanson [12]) shows a 1965 estimate of shale resources in the world. Because of the limits these authors have placed on the shale grade in their estimates, resources with oil yields lower or higher than the limits given are not included. In a 1980 update of estimates of United States resources, Smith [13] notes that an estimate of the extent of the resource based on grade assumes that the technology will remain as it is now. He presents his data for U.S. shales in terms of the total resource, without reference to grade. There is no convenient estimate of world resources that includes the total resource.

Because of the uncertainty about the technology of utilization of the shale resource and because of uncertainties in world estimates, no attempt is made to estimate recoverable resources. The amount of oil that can be recovered will depend on factors like the location of the reserve, its richness, 
geographic features associated with the resource, and the kind of processing required. The economic feasibility of a recovery scheme is influenced by the availability of other fuel resources in a particular country, the extent of its need for fuel, and the economy of the country. Resources that the United States judges as not economically viable either because of the leanness of the resource or the extent of the operation are commercially exploited in China and Estonia [14]. Chinese shales are lean (e.g., 21-42 L/tonne,1 5-10 gal/ton); the Estonian shales are rich (166.89 L/tonne, 40 gal/ton) but the operation is limited in extent.

Table 3 shows the figures for United States shale reserves as updated from Duncan and Swanson's data by Smith. In Figure 3, the major shale-bearing areas of the United States are depicted [13]. These are generally designated as eastern and western shales. The designation western usually refers to the abundant Green River shales of Colorado, Utah, and Wyoming. Smaller deposits exist in Montana, Idaho, Nevada, Oregon, North and South Dakota, Nebraska, Texas, and Alaska. The eastern shales are found principally in Ohio, Michigan, Indiana, Kentucky, Tennessee, and Alabama with smaller deposits in New York, Pennsylvania, and North Carolina. Table 4 shows estimates of the eastern reserve when a recovery process specifically developed for eastern shales is used [15].

Scotland, China, and Estonia (USSR) have produced oil from shale commercially. China and Estonia still do today. Several other countries produced small quantities of transportation fuel from shale during World War II, when other supplies were severely limited.

\subsection{Eastern and Western Shales}

Eastern and western United States shales are distinctly different in nature and in their response to processing and analytical variables. They differ in geological age, kerogen structure, and oil and mineral content. The differences which exist within each region are less striking than those between east and west. The analytical procedures by which oil yield is evaluated and the processing schemes which give best results differ for these two groups of shales. These differences are discussed in the appropriate sections of this report.

Figure 4 shows the locations of the four basins included in the Green River (western) formation: Green River, Washakie, Piceance Creek, and Uinta [13]. These lacustrine shales are believed to have deposited from ancient Lake Uinta some 60 million years ago during the Eocene age. This lake expanded and contracted during its lifetime and sometimes was saline in nature and sometimes not. Thus the deposits vary according to the nature of the lake at the time of deposition, particularly in their mineral composition [3]. The Mahogany zone is unusual in its very uniform mineral composition. In western shales aliphatic hydrocarbons predominate; nitrogen-bearing heteroatomic compounds are more abundant than in eastern shales.

1 A tonne is a metric ton. 
The eastern shales deposited from marine sources some 200 million years ago. Some are Devonian, some Permian, and some Mississippian. Their organic content is lower than that of western shales; aromatic species and pyrite are more abundant. An estimate of the extent of each of the shale deposits in each area is given in Table 4 [16]. The location of the DevonianMississippian deposites is shown in Figure 3.

Table 5 lists the organic and mineral species which commonly occur in eastern and western shales $[13,16]$.

\section{CHARACTERIZATION AND ANALYSIS}

\subsection{Characterization}

For many years the sole characterization information given for shale was its oil yield as determined by the Fisher Assay (FA). Today individual research reports sometimes include additional information: percent organic carbon, percent aliphatic and aromatic carbon, elemental analysis, proximate analysis, calorific value. However, there is no consensus, nor common practice, about what information should be supplied to ensure maximum usefulness of the data that are generated. Specification of the exact location of the shale source and information about inorganic (mineral) species are other serious omissions.

The only test procedure that is specified and universally used is the FA analysis. The American Society for Testing and Materials has published a test method for the FA [17], but the method does not specify a particular heating rate. The use of different heating rates during the assay introduces considerable variability into the results [18]. In contrast, the coal science community has long used extensive characterizations. Because of this wealth of information about coals studied, valuable correlations have been developed. Also, rigidly specified procedures exist for the determination of characterization properties [19]. In addition, the coal science community has agreed on the characterization information that ideally should be provided to permit improved process design and maximum development of correlations [20].

Characterization efforts for shale are in utter chaos by comparison with coal. Some agreement among shale scientists as to what kind of information will be useful for the understanding of shale reactions, process design, and the development of correlations is an immediate need. Then, as properties and process research proceeds, we will begin to amass the information needed to understand the processes, to modify them, and to develop correlations useful for modeling both processes and properties.

\subsection{Analysis}

Analysis procedures appropriate for shales include those used to determine the potential oil content and/or the nature of the organic component as well as others suitable for identifying the mineral species present. 


\subsubsection{Mineral}

Mineral species are commonly identified by optical methods or by $\mathrm{x}$-ray diffraction techniques. X-ray techniques are not sufficiently sensitive to give good quantitative estimates, nor will they identify minerals present in small amounts. Optical techniques are particularly difficult to use for most shales because of the small grain size of the mineral particles.

Quantitative estimates of a few minerals (nahcolite, dawsonite, nordstrandite) cannot be obtained satisfactorily by these techniques. These minerals can be solubilized and then analyzed successfully by standard instrumental methods [21,22]. In some instances all inorganic species present are determined by atomic absorption spectroscopy [23].

\subsubsection{0il yield}

Most analytical efforts have been directed toward determining the oil yield and the nature of the organic phase. The estimate of oil yield for a particular shale customarily has been obtained from the Fischer Assay. The original FA procedure, based on a retorting method for coal that used a retort design suggested by Fischer and Schrader [24], predicted the yield of oil shale from retorting; the assay required about six hours $[25,26]$. Pyrolysis of the shale released the kerogen as hydrocarbon vapor. When cooled, some of these vapors condensed to a shale oil; the light hydrocarbons remained in the vapor phase.

Modifications to this procedure (mesh size, heating profile, aluminum spacers) improved the oil yield estimates and reduced the assay time to about two hours (modified Fischer assay [27]). Further modifications of the FA procedures allowed more precise determination of individual hydrocarbons, carbon monoxide, and acid gases; a complete material balance closure could be obtained. With the addition of elemental analysis, the organic carbon, nitrogen, and sulfur balances can be calculated. In this way both product balances and material balances are obtained (material balance assay [28-30]).

All assay procedures for oil shale are evaluated by comparison with FA results. This comparison in turn strongly influences the evaluation of shale resources. This is somewhat unfortunate as the FA is intended to assay geologic deposits, not retorting parameters, and it is the retorting parameters that determine the actual oil production.

The ASTM procedure stipulates that agreement between replicates should be \pm $4.2 \mathrm{~L} /$ tonne ( \pm 1 gal/ton); agreement among laboratories should be \pm 8.3 L/tonne ( \pm 2 gal/ton) [17]. The error and scatter in FA procedures and results have rarely been considered. The failure to include such statistical information introduces considerable uncertainty into oil yield determinations and into judgments of these newer analytical procedures, many of which represent considerable savings in time.

In particular, FA procedures have been found to give false estimates of oil yield for eastern shale. This has caused these shales to be considered unsuitable for commercial development, despite the many potential advantages of an eastern shale industry. The process yield from Eastern shales should 
be comparable to that from western shales with the same carbon content. Assay procedures suitable for eastern shales have been developed. These include hydroassaying procedures, rapid-heat-up (RHU) procedures, and the Rock Eval assay. The Eastern shales are now considered to be sufficiently rich for exploitation; however, they do have a greater aromatic and lesser aliphatic content than western shales. Development of western shale is favored because its high aliphatic content is more suited for the production of liquid transportation fuel. Also, the high aromatic content of eastern shale intensifies potential pollution problems.

A hydroretorting assay procedure [31] has been found suitable for prediction of oil yield from the HYTORT ${ }^{2}$ process, which has been developed by the Institute of Gas Technology. For eastern shales, the richness estimated using this procedure is significantly greater than the FA yield for the same shale. For the hydroretorting assay, a small oil shale specimen is retorted with hydrogen at about $5 \mathrm{MPa}$ pressure. The yield obtained with the FA for a New Albany shale from Kentucky was $52.2 \mathrm{~L} /$ tonne (12.5 gal/ton); the yield predicted for the same shale by hydroretorting was $117.7 \mathrm{~L} /$ tonne (28.2 gal/ton). The FA yield suggests that the deposit is uneconomical to work; the HYTORT results predict the potential for an economically feasible process. In developing the hydroretorting assay, care was taken to ensure that the results were identical with those for FA results when a western shale was being studied.

A rapid-heat-up (RHU) assay [32] for Eastern shales is an alternative procedure in which the heating rate is about $55 \mathrm{~K} / \mathrm{min}$ versus $12 \mathrm{~K} / \mathrm{min}$, as for the FA. The RHU assay uses a fluidized sand bed, collects condensables at a slightly lower temperature than the FA, and measures noncondensables with a wet test meter. No temperature gradient exists in the shale because a very narrow bed is used; all the shale is essentially at the same temperature. For the same shale, the gas yield in this process is $15-50$ percent greater than that from the FA; the oil yield is from 85-100 percent greater. Rubel et al. [33] and Margolis et al. [34] describe an analytical pyrolysis assay which is successful in predicting yields from fluidized bed retorting techniques, which are extreme RHU processes. They report yields that are 130-145 percent of FA. Rubel and Audeh provide the first comparison of a variety of RHU procedures in different laboratories [35].

The Rock Eval process was developed by Espitalie as a source rock analysis tool [36]. It is widely used in Europe and Canada, and by U.S. industry. The assay uses a small charge (milligram quantities) and reports results in

2 Certain commercial processes are identified in this paper in order to specify adequately the experimental procedure. Such identification does not imply recommendation or endorsement by the National Bureau of Standards, nor does it imply that the process identified is necessarily the best for the purpose. 
terms of hydrocarbon content, hydrogen and oxygen indices (related to van Krevelen $\mathrm{H} / \mathrm{C}$ and $\mathrm{O} / \mathrm{C}$ ratios), and the temperature of the rate of maximum oil evolution. It can be done in individual laboratories within about 20 minutes.

\subsubsection{Organic}

Standard methods of analysis for organics have been applied both to the shale and to the oil generated in the process. Miknis summarizes the standard analytical methods that have been used to evaluate the organic component of shales [37]. For the most part, these analyses are related to the amount of kerogen in the shale rather than the amount of oil which can be produced. The methods discussed by Miknis include organic elemental analyses including sulfur and oxygen, determination of organic carbon from combustion measurements, organic hydrogen from nuclear magnetic resonance (NMR), laser pyrolysis chromatography, thermal chromatography, correlation with the specific gravity or density of the shale, ultraviolet (UV) and infrared (IR) spectroscopy, including Fourier Transform IR (FTIR), gas chromatography coupled with mass spectroscopy (GC/MS), electron paramagnetic resonance (EPR), fluorescence spectroscopy, various NMR techniques, and thermal analysis. The NMR techniques, which have provided a real breakthrough in shale analysis, are discussed at length by Miknis.

The use of various solid-state NMR techniques represents a significant advance in analytical capability for shale. Both proton and C-13 NMR techniques have been used to identify saturated and unsaturated aliphatics and aromatics [38,39]. Through the use of cross polarization and magic angle spinning (CP/MAS), it is possible to determine the relative aliphatic and aromatic contents of the raw shales [40]. Trewhella et al. studied the structure of Green River oil shale kerogen with a combination of advanced NMR techniques [41].

\subsubsection{Thermal analysis}

Thermal analysis techniques have been used to estimate oil yields. Oil yields can be estimated either from weight loss determinations by thermogravimetry (TG) or from heat of decomposition determinations by differential thermal analysis (DTA). These techniques are simple and rapid but may have little validity for raw shale because of complicating mineral reactions in the temperature region where oil loss occurs. In addition, these techniques have poor quantitative accuracy and are readily misinterpreted. A linear correlation between enthalpy of decomposition and oil yield, reported by one investigator [42], was shown to be fortuitous by subsequent investigations [43]. The linearity observed by the first investigator was a result of the use of shales from the Mahogany zone, with its remarkably uniform mineral composition. A random selection of shales showed no correlation between enthalpy of dissociation and oil yield. In other studies, Johnson et al. [44] used a specially built apparatus that permitted simultaneous determination of mass loss and thermal effects. With this equipment and their considerable background, both in shale and thermal methods, they found variations from FA values of less than 10 percent for Mahogany zone shales; for shales from other sources, the differences between 
thermal analytical and FA results were from 1.6-28 percent [45]. A carbon dioxide atmosphere shifts some of the mineral peaks so that some of the interferences are less detrimental.

\subsubsection{Electromagnetic}

Judzis et al. [46] suggest microwave radiation for the measurement of the organic content of a shale. A strong correlation exists between the dissipation of microwave energy and the organic richness. The dielectric behavior of Green River oil shale was studied in the microfrequency range as a function of shale richness, its density, and the frequency of the radiation. They found a strong correlation between shale richness as determined from FA results and either the imaginary term of the dielectric constant or the loss tangent (ratio of real to imaginary permittivity). However, as the accuracy is given as $\pm 14.2 \mathrm{~L} /$ tonne ( $\pm 3.4 \mathrm{gal} / \mathrm{ton}$ ), this procedure offers little advantage over FA techniques.

Jesch and McLaughlin [47,48] have investigated the use of a high-frequency electron mapping (HFEM) technique that would facilitate evaluation of the efficiency of rubblized modified in situ retorts before ignition. Their measurements enabled them to determine the complex permittivity of disk specimens of oil shale, cut parallel to the bedding plane, from room temperature to $773 \mathrm{~K}$. All effluents were collected. The shale began to retort about $650 \mathrm{~K}$; all emission of oil and gases had ceased by $750 \mathrm{~K}$. When the specimens were cooled to room temperature and remeasured, the properties were almost identical to those obtained before heating. Thus, contrary to expectations, removal of oil did not affect the electrical properties significantly, as had been suggested. Measurements showed an uncertainty of \pm 1-2 percent in dielectric constant and of \pm 5 percent in the imaginary part of the permittivity at room temperature. Moisture content and density were found to influence the permittivity.

\section{THERMAL PROPERTIES}

\subsection{General Considerations}

Because of the nature of the processing that shale undergoes, there is a need both for kinetic and equilibrium thermal property data. Kinetically correct heats are needed to assess energy needs for retorting (or pyrolysis). These processes occur so rapidly in the raw shale that equilibrium conditions are not met. However, equilibrium does prevail for the spent/burnt shale which are used as circulating hot solids in some retorting processes. For these components of the processing cycle, equilibrium data are required.

The thermal properties of potential interest for oil shale include heat of combustion, heat of retorting, heats of reaction of organic components and minerals, thermal conductivity, thermal diffusivity, thermal expansion, and specific heat. The heat of retorting includes contributions from specific heat and from the heats of the various reactions which occur during retorting. 
The ability to process large volumes of shale to pyrolysis temperatures depends on heat capacity, thermal conductivity, and the heat associated with the various reactions which occur. The heat capacity provides information about the total energy required to raise the temperature of the shale; thermal conductivity, the transfer of the heat supplied through the shale. Heat capacity and thermal conductivity are functions of temperature, shale grade, orientation with respect to the bedding plane, and the extent of pyrolysis. Differential thermal analysis gives a qualitative picture of endothermic and exothermic reactions that are occurring; calorimetry gives quantitative information about these reactions.

The published data on thermal properties of oil shale are scarce; no comprehensive or systematic studies published in the United States have come to our attention in our survey of the literature. Reliable studies are limited in application. Thermal data on shale are rarely accompanied by statistical information. Thermal property studies need to be expanded to assess the effects of different variables on the measurements themselves, to refine the measurement procedures so that they will be transferable, and to determine the statistical validity of the results. Statistical evaluation of thermal measurements is needed to provide information about inherent variability and would be part of the development of transferable measurement procedures. Once a reliable measurement process is developed, studies closely related to process variables and practical problems will be feasible.

Some general deficiencies in our knowledge of thermal properties of shale can be identified by comparison with similar data on coal. As indicated previously, there is no agreed upon characterization of shale specimens like that recommended for coal. Because there is no accepted general characterization scheme for shale, the work published is for the most part on poorly characterized shales (at least by comparison with customary characterization of coal). A broad range of generally accepted testing and evaluation procedures, similar to the ASTM procedures for coal [19], do not exist. As a result, measurements of a particular property on the same shale in two different laboratories may differ considerably. Procedures by which reliable data can be generated must be developed. In addition, most published studies are for Green River shales; measurements must be extended to a variety of well-characterized shales.

Most thermal property measurements have been made on Green River shale from the Mahogany zone, where the variability in mineral content is slight. Similar measurements on shale outside of the Mahogany zone, other western shales, and eastern shales are needed. This is true especially since we now know, as a result of recently developed procedures, that there is far more potential than formerly realized in eastern shales. These shales, too, must be included in the data base from which correlations are developed.

Because thermal property data on well-characterized shales are scarce, no useful correlations among thermal properties or between thermal properties and other properties of shale have been developed. For coals, good predictions of thermal properties from analytical data have been made $[49,50]$. The validity of such correlations that will be developed for shale 
in the future depends on both the extent of the data base and the reliability of the measurements. It would be of great value to those developing

correlations to have access to as much data as possible. Proprietary thermal property measurements, some of which can be expected to be reliable, have been made. Since all concerned stand to benefit if valid correlations are developed, every effort should be made to find a way to release as many of these data as possible while still protecting proprietary interests. It would be advantageous to work out agreements that give some laboratories, perhaps selected government laboratories, access to the data for development purposes without releasing figures in a way that would harm proprietary interest.

\subsection{Thermal Analysis}

The suitability of differential thermal analysis (DTA) and thermogravimetric analysis (TG) for the determination of thermal properties is questionable. DTA is generally a qualitative technique and has marginal utility in determining thermophysical properties of a material as complex as shale. Though attempts have been made to declare the technique quantitative, its accuracy is questionable. Even differential scanning calorimetry (DSC), a more accurate measurement technique, requires carefully developed operating procedures that must be adhered to rigidly [51]. DTA does not provide a way of separating contributions from various simultaneous or overlapping reactions that occur as shale is heated. The practice of determining heat effects associated with the reaction of a pure mineral and then applying a corresponding correction to a composite curve ignores the interactions which may be occurring among various mineral species and between mineral and organic moieties. These interactions, some of which are catalytic, are extremely complex; simple additivity cannot be assumed.

Thermogravimetric analysis provides a way of following the mass loss of a material as a function of temperature/heating rate. It does indicate the temperature at which the shale begins to decompose. When used in conjunction with analytical procedures, useful information about products generated can be obtained. However, the technique does not provide direct information about thermal properties. Its principal utility for shale is for kinetic studies.

\subsection{Status of Individual Thermal Properties}

\subsubsection{Heat (energy) of combustion}

A heat of combustion is the heat associated with a combustion reaction. Thermodynamics considers it to be the heat associated with a reaction in which the reactants and products are well-defined. For fuels, this requirement presents difficulties. The initial and final states associated with the reaction must be known accurately; the combustion most often takes place in an oxygen atmosphere. The heat of combustion is usually determined experimentally as a constant volume process (an energy of combustion) in a bomb calorimeter. Either adiabatic or isothermal shield techniques can be used. 
There is a serious flaw in the way energies of combustion are determined for materials with fossil origins, which usually contain sulfur or nitrogen. The first law of thermodynamics requires that the initial and final states of the system being measured be known accurately. When sulfur compounds undergo combustion, oxides are formed. Some of these are in the form of dioxides; some are trioxides. When this situation prevails, the final state of the system is not known accurately. For determination of the energy of combustion of sulfur-bearing materials, the bomb should be charged with oxygen along with small amounts of nitrogen and water. When sulfur oxides are formed on combustion, the nitrogen catalyzes the conversion of the dioxide to trioxide; thus all the oxide of sulfur exists as trioxide. The bomb is rotated during the combustion so that a homogeneous solution of sulfuric acid is formed in the bomb. The sulfur content can then be determined correctly and corrections to the energy of combustion made [52]. The error associated with the sulfur compounds is frequently between 10-20 percent; it can be as high as 100 percent. The same principles apply to the complex mixture of nitrogen acids that may be generated, but the nitrogen error has been shown to be not as serious as that from sulfur.

A further problem can be introduced by the mineral species present in fossil materials. Their oxidation contributes to the measured energy and also can cause different end products to be present. These products must be identified in order to know the final state of the system. Measurement of the thermal properties of organic concentrates, which largely eliminate the mineral species, helps to avoid problems introduced by minerals. However, it does not solve the problems encountered in processing shale that are due to its mineral content.

No measurements of energies of combustion of any fossil materials in a rotating bomb system have been published in the open literature. Thus, all reported measurements are expected to have some error. Some proprietary measurements have been made on coal, but as no measurements were made on the same samples by classical bomb calorimetric procedures normally used for coal $[53,54]$, a comparison of results by the two methods is not possible. An estimate of the correction for sulfur and nitrogen in these measurements was about \pm 5 percent. This error may not seem overly serious, but if translated to energy, it amounts to about $2208 \mathrm{~kJ} / \mathrm{kg}$. For a process involving tons of coal, a tremendous amount of energy is involved in that miscalculation. For good design, an accuracy of 0.2 percent is desirable [55].

The facilities and expertise needed for accurate measurement of the heat of combustion are scarce and expensive. Thus routine determination of combustion heats by rotating-bomb calorimetry is not economically feasible. Because of these limitations, a static oxygen bomb will continue to be used for routine measurements. The shale industry needs to obtain comparisons, for some representative shales, between results obtained by truly appropriate procedures (rotating bomb) and the static bomb procedures customarily used for heat of combustion. The development of an adequate data base would help in error evaluation. As more information about the chemical constitution of shale becomes available, group additivity relations should be investigated. 
As shale technology advances, heats of formation of the shale and of all its products will be required for model development. This information is obtained from heat of combustion data as a small difference between large numbers. The inaccuracies in the large numbers (heats of combustion) are multiplied by a factor of 10 when obtaining heats of formation from them. The resulting heats of formation are seriously in error. The uncertainty about the heat of formation of coal has been a serious problem in modeling for some time [56].

Muehlbauer and Burnham estimated the heat of combustion of raw shale [57] and Burnham et al. that of retorted and spent shale [58] by thermochemical estimates and linear regression of experimental data. These data were needed for modeling the modified in situ process under study at Lawrence Livermore National Laboratory (LLNL). For the experimental measurements on which this work was based, the shale was ground and compressed into pellets before use. These results were flawed by the presence of unburned material, frequently found on opening the bomb. In addition, since the bomb used could not be rotated, the sulfur and nitrogen corrections have not been made as effectively as they could be [59].

Measurements of the heats of combustion of retorted and burnt shale by Burnham et al. [58], by much the same technique, aided them in identifying and quantifying reactions. These exothermic and endothermic reactions occur when retorted shale is burned above $800 \mathrm{~K}$. Corrections appropriate for the composition differences of burnt, retorted, and acid-leached specimens were applied. An equation that was developed for determining the heat of combustion from the composition of the shale assumed that the heat of combustion included contributions from the char, the iron sulfides, carbonate decompositions and the formation of a glass. The equations proposed by Burnham et al. are realistic in light of their discussion of mineral contributions and the corrections applied. They report considerable complication introduced in this work by mineral reactions and point to a need for study of the chemistry of combustion in order to improve estimates of combustion heats. From the analyses of 66 retorted shales, they determined the empirical formula to be $\mathrm{CH}(0.4) \mathrm{N}(0.07)$. Values for the contributions of the organic carbon, nitrogen, and hydrogen are suggested; a measured heat of combustion for demineralized shale is reported as well as that for the raw shale.

Corino and Turnbull devised a method of measuring the heat of combustion of spent shales in a differential scanning calorimeter (DSC) in an oxygen atmosphere and report good agreement with bomb calorimetric results when these latter are extrapolated to DSC conditions $[60,61]$.

Mraw et al. have adapted techniques originally developed for the heat of retorting of shale to measure the heat of combustion of shale. These techniques are described in the next section of this report. By working in a moist oxygen atmosphere at optimum oxygen-flow rates, their results for well-known materials agreed with literature values within a few percent $[62,63]$.

Ringen et al. [64] have calculated heating values (calorific values) from the 
elemental composition of fossil fuels (oils, crude oil residua, and coals) by means of the Boie equation [65]. The calculation of the heat of combustion in this manner is desirable because of the ease and rapidity with which accurate values for elemental composition can be determined. The very high mineral matter content of shale complicates the application of this technique to shales. Smith and Young [66] applied the Boie equation to the elemental composition of organic concentrates of raw New Albany shales, which they had determined. Ringen et al. have used the literature data for an organic concentrate of Green River shales [67] to apply the Boie equation. They state that the contributions from $S, N$, and 0 combined are less than 1 percent; results calculated from the complete analysis ( $\mathrm{C}, \mathrm{H}, \mathrm{N}, \mathrm{O}, \mathrm{S}$ ) differ from those calculated from only the $\mathrm{C}, \mathrm{H}$ terms by about 1 percent for both the New Albany and the Green River shale. These statements are misleading. When the whole shale is being used, the inorganic components contribute significantly to heteroatom concentration. Thus Ringen's estimate is not valid for raw shales, which will be used in processing.

\subsubsection{Heat of retorting}

The heat of retorting is the total enthalpy required to heat a shale from ambient temperature to the decomposition temperature and convert it into gas, oil, and spent shale. It includes the enthalpy involved in the increase in temperature (sensible heat) and that associated with any reactions, organic or mineral, that occur in the decomposition process.

The earliest reliable enthalpy measurements on shale were made by Shaw in 1947 [68]. He determined the mean heat capacity of a number of shales varying in grade from 4.2-372 L/tonne (1-89.2 gal/ton) over the temperature range 340 to $505 \mathrm{~K}$. Water was the medium for raw shale and kerosene for the spent shale. His data were converted to enthalpies and published as such.

Sohns et al. [69] designed a retort that was capable of holding about 20 kilograms of raw shale. They equated the heat of retorting to the difference in heat content of an inert gas as it entered and left the retort. By use of an adiabatic shield, they reduced heat losses to a level that could be calculated accurately.

Wise et al. [70] improved on the measurements of Sohns et al. for raw shale by correcting for the enthalpies of products leaving the retort. They extended the measurements that had been made on spent shale and also reported results for burnt shale. Wise et al. worked with a smaller version of the adiabatic calorimeter that had been used previously. They calibrated their system carefully for heat losses and report results obtained with a calibrant in addition to shale results.

Corino and Turnbull $[60,61]$ used a commercial calorimeter which is based on the Tian-Calvet principle [71] to measure heats of pyrolysis of Rundle oil shale. They report satisfactory agreement with previous workers. They have also measured the heat effects associated with the mineral species present in the shale they studied.

Mraw and Keweshan have developed a new technique [72], which they call 
ballistic calorimetry, that uses a specially constructed Tian-Calvet calorimeter [73]. It is essentially a drop calorimetric method which can separate the instantaneous heats, related to the organic content of the shale, and longer term (1.5-2 hours) effects, related to mineral reactions. They established the validity of the method for pure substances [72] and for mixtures and substances of industrial importance [74]. Through the use of this technique, they are able to separate the effects of kerogen decomposition from the mineral reactions [75]. Their results are consistent with those of Sohns [69] and Wise [70].

Carley has examined existing data for heat of retorting and presented a critical analysis [76]. Camp has reviewed this analysis and extended it to specific heat [77]. These authors conclude that extant data for these quantities are often contradictory and sometimes seriously in error.

\subsubsection{Specific heat}

A serious problem may be encountered in attempting to measure the specific heat of oil shale. Heat capacity and specific heat are thermodynamic properties. As such they refer to a system in a particular state. If the system under study changes during the measurement, it is not appropriate to call the result a heat capacity or a specific heat.

The mineral content of raw shale may complicate the determination of specific heat in just this way -- because of competing mineral reactions. Many of the minerals found in shale will react in the same temperature region in which the shale decomposes or is retorted. Nahcolite, dawsonite, nordstrandite, and hydrated clays are particularly troublesome. Thus what one hopes to measure as specific heat often is complicated by the enthalpy of the mineral reactions and of the reactions of the organic components of oil shale. The first heating of the material includes both contributions. Subsequent heating should give values that resemble true specific heats. However, the salient question here is: the specific heat of what? When the material has reacted, it is different from the starting material. The best one can do is consider it to be the specific heat of a spent or partially spent shale, prepared at a particular temperature. This is much like the boxing technique used by singer and Tye [78]. The difference between the initial and repeat curves can be evaluated to give the enthalpy of the mineral reactions that are actually occurring. However, it is difficult to determine the exact nature of the mineral reaction in a material as complex as an oil shale.

Gavin and Sharp [79] report early specific heat measurements of an unidentified shale. Shaw [68] measured mean specific heat but reported his results as enthalpies. This work has been discussed previously.

In measurements of the specific heat of Green River shales by DSC, Taylor and Groot [80] noted the existence of an endotherm on the first heating; second and later heat capacity scans were uneventful heat capacity scans with a gently rising slope. Corino and Turnbull $[60,61]$ report the specific heats of raw, spent, and burnt Rundle shale. Gilliam and Morgan, in DSC measurements of the heat capacity of eastern oil shales from ambient temperature to $473 \mathrm{~K}$, noted interferences from water present in their system 
[81]. No comparative evaluation of these above results can be made at this time because the studies involved different shales under different experimental conditions. If equilibrium conditions were not met, the comparison will be difficult. Other specific heat measurements can be found in the literature or have been communicated to our laboratory, many of which have been made by DSC or DTA. These are not discussed here because problems associated with these data have not been solved.

\subsubsection{Thermal conductivity}

Thermal conductivity measurements of solids, especially solids which may contain defects or undergo reaction, are difficult to do properly at best. The extension of these measurements significantly above room temperature indeed presents a challenge. Problems anticipated include integrity of the specimen, contact problems between sensor and specimen, and contributions from radiative heat transfer. At high temperatures radiation will contribute significantly to heat transfer.

A few thermal conductivity measurements for raw and spent Green River shale are reported in the literature. These are isolated measurements on poorly characterized shales. There have been no systematic studies, nor are estimates of accuracy and precision given.

Tihen et al. [82] measured the thermal conductivity of raw, spent, and burnt shale as a function of grade and orientation with a transient line source probe. They used five replicate specimens at temperature ranges that were suitable for the shale species being studied. Thermal conductivity varied inversely as shale grade. Conductivity decreased from raw through spent to burnt shale. These authors used the same equipment but different measurement procedures to determine the thermal diffusivity of the same shales.

Taylor and Groot [80] used a laser-flash technique with disk specimens to measure the thermal diffusivity and a scanning calorimeter to determine the specific heat of a series of shales. By use of these values and the density of the specimens, they calculated thermal conductivity; no characterization information is reported for the shales. They observed an endotherm on the initial heat capacity run which extended from 333-573 K. Repeat runs on preheated samples showed uneventful heat capacity curves. The thermal conductivity values, obtained from the measured heat capacity, density, and diffusivity, decreased with increasing temperature up to $673 \mathrm{~K}$; above this temperature, there was a sharp drop in conductivity, which was attributed to the release of oil.

Nottenburg et al. [83] used a thermal comparator technique to measure the thermal conductivity of two Green River shales from 298-628 K. Their specimens varied in grade and orientation. Results are presented graphically and are comparable to others in the literature.

Gilliam and Morgan also used a thermal comparator technique to measure the thermal conductivity to $473 \mathrm{~K}$. Again, they refer to interference from free, adsorbed, and absorbed water [81]. 


\subsubsection{Thermal expansion}

Smith and Johnson [84] measured the thermal expansion of shale in a specially constructed dilatometric cell, which unfortunately has not been described in detail. The solid specimen was cut perpendicular to the bedding plane and heated at $10 \mathrm{~K} / \mathrm{min}$. They state that the expansion of the organic moiety is 20 times that of the mineral matter. In a $146 \mathrm{~L} /$ tonne (35 gal/ton) shale, the oil is about 40 volume percent. They estimate the expansion coefficient for the organic matter to be $3.4 \times 10(-4)$ per $\mathrm{K}$, which is similar to values obtained for paraffin and asphalt. This estimate includes interferences from mineral species. Two regions show rapid increases in length: $463-498 \mathrm{~K}$ and $673-758 \mathrm{~K}$. In the first of these regions, the core increased in length about 8 percent and fissures began to develop. A major force contributing to the development of fissures is the existence of differing oil content of different layers of the shale bed and the consequent stress induced in the layers. Decomposition begins in the 673-758 $\mathrm{K}$ temperature region; the accumulated increase in core length by $758 \mathrm{~K}$ is 14 percent. By contrast from $758-1273 \mathrm{~K}$, the core expands only 1.1 percent.

Duvall et al. [85] measured the free expansion of raw shale as a function of grade, orientation, and heating rate, from 298-698 K, with a quartz push-rod dilatometer. Shale grade was determined from a correlation between shale grade and specific gravity [86]. They write of a small expansion from 350-550 K, attributed to the development of fissures, and a much greater expansion between 650-675 K; this was accompanied by decomposition of the shale and serious distortion of the specimen. The graphical data presented and the very great magnitude of the error bars shown make it difficult to support these conclusions. Variation observed as a function of heating rate was well within the error of the measurements.

Khan has used a high-pressure microdilatometer [87] to study the expansion/contraction behavior of shales and of a kerogen concentrate as a function of several experimental variables [88]. He observed limited expansion up to about $773 \mathrm{~K}$; above that temperature, he observed contraction, which for some shales far exceeded any expansion that had occurred.

Gilliam and Morgan measured thermal expansion with a commercial dilatomer to $473 \mathrm{~K}$; they report expansion to this temperature, followed by major deformation of their specimens above it [81].

\subsubsection{Heat of immersion}

While raw shale does not exhibit the extreme porosity that coal does, the spent shale does. A relatively untouched field of investigations involves interactions between raw, spent, or burnt shale and water, hydrocarbon liquids, and mixtures of them. Such interactions do exist during oil shale processing. 


\subsection{Postscript}

Essential to any development of measurement procedures for thermal properties are 1. a critical survey of existing data on materials, properties, and methods, and 2. development and refinement of measuring procedures to be used with well-characterized materials. This statement implies that appropriate decisions have been made regarding suitable characterization. The first of these tasks has been furthered by this report, though a quantitative evaluation of thermal property data is not included here. The quantitative evaluation and publication of thermal property data needs to be completed; the second task remains essentially unaddressed.

Some of the pitfalls that attend measurements of thermal properties of oil shale have been pointed out above. They serve to emphasize that thermal property measurements on solids, particularly at elevated temperatures, are difficult to make. The complexity of shale and potential interferences from reactions complicate these measurements. These difficulties make the two aims enumerated above even more crucial.

\section{PROCESSING AND BENEFICIATION}

\subsection{History of Commercial Production}

Commercial exploitation of oil shale reserves has been occurring in some parts of the world and at some times since the early 1800's. In the United States there were working retorts in the Ohio River valley; the discovery of oil in Pennsylvania in 1859 put an end to their operation. The same holds true for much of Canada. Mature oil shale deposits in Scotland remained in production as did retorts in the Eastern Provinces of Canada, particularly Nova Scotia.

The U.S. Bureau of Mines maintained a small research program. This program became more active with the advent of World War I. But the discovery of oil in Texas in the late 1920's again brought the cycle to a low point. During World War II, intensified research was carried out in the United States and Australia. The low price of crude oil in the late 1950's brought most of these efforts to a halt.

The world oil crisis precipitated by the actions of OPEC in the 1970's again gave birth to renewed research. Again, these efforts were largely terminated by the drop in oil prices in the early 1980 's.

The United States has tremendous reserves of oil shale to supply a synthetic fuels industry. The technology needed to utilize these reserves is feasible but must be developed. This development will require a long-term commitment.

\subsection{Oil Shale Processing}

The older processes by which crude oil is obtained from oil shale can be divided into three groups: above-ground, in situ, and modified in situ retorting. The newer processes are still in laboratory development, but most 
would be classified with above-ground retorting. The fundamentals of each of these process groups, their advantages and disadvantages, and the present status of each technology will be discussed in turn. All the processes generate a crude oil which must be prerefined before any further processing is carried out.

\subsubsection{Above ground}

Above-ground retorting in a wide variety of retorts and processes is the oldest of the processing technologies. The shale is brought to the surface by traditional mining techniques and there processed in retorts. Oil removal from the rock is most effective in these processes because it can be controlled better. However, tons of spent shale require disposal. The shale expands as it is processed, so the spent shale cannot just be put back into the mined area underground. In addition, the treatment of the retorted (spent) shale requires large amounts of water. As the major portion of the domestic shale slated for near term exploitation is in the west, where water is scarce, this need for very large amounts of water is a distinct drawback. A third serious problem arises from the porosity of the completely processed shale, much of which will be reinserted into the mined areas. It facilitates the leaching of deleterious species, principally inorganic, into the ground water.

In above-ground retorting, a hot zone is propagated through the retort by means of countercurrent flow of hot gases or hot solids. The flow may be from the top down, from the bottom up, or horizontal. By these means oil can be liberated from the solid. The technical challenge is to do so at a cost that makes the product competitive.

The majority of processes which have reached the pilot-plant stage or actual production involve above-ground retorting. Hot gases are used in what are considered first-generation processes. The thrust to use hot solids to heat the charge has resulted in second-generation processes; there is no certainty at present that they can be successfully developed. Factors which have been studied include retort volume, heat exchange, the maintenance of appropriate temperatures in various zones, mixing in the retort, atmosphere, residence time, power and water requirements, and waste disposal, including gases, solids, and water.

Variants of above-ground technology being investigated actively today include various fluidized-bed or cascading-bed techniques. These heat the shale more uniformly, thereby increasing the possibility of attaining more nearly maximum yields. High processing rates and heat transfer result in very short residence times. Therefore, there is less charring and coking of the oil, which results in higher oil yields. Crucial variables include the retorting temperature, the atmosphere, and the pressure in the bed.

\section{2 .2 In situ}

In situ oil shale processing takes place entirely underground. The shale bed must be fractured or rubblized by explosives or by hydrostatic pressure. Then combustion of a portion of the bed is initiated and the burn is 
propagated through the bed. The oil generated by this means is pumped to the surface where prerefining is done. In situ processing is not useful for rich shales because of problems generated with permeability. It is suitable, however, for lean shales which are uneconomical to process in above-ground retorts.

The mining operation is eliminated as is the problem associated with disposal of spent shale. It merely remains in the mine. Water requirements are lower. Heat is supplied by direct combustion or steam injection. Major problems are encountered in fracturing the bed, establishing the required porosity, measuring temperature at a remote underground site accurately, sustaining the burn, overcoming coking or cracking of the oil, and with pollution associated with the spent shale. The problems associated with contamination of ground water and aquifiers by leaching of spent shale remains, whether the shale has been reinserted into the mine from above ground or whether it was generated in situ. As with all in situ processes, the burn will follow the path of least resistance. As a result, oil is not removed from large portions of the bed. Control of the path of the burn is not practical. Drilling costs are high; environmental contamination problems. are serious.

In situ processes were explored widely during the 1970's but are not receiving much attention at present. Most of the information has been gained from laboratory simulations since true field tests are hard to control and evaluate. While the need to dispose of the spent shale is eliminated, the problems of heating and sustaining the burn and of subsequent pollution are tremendous. Important process parameters include the type of heat source, the means of propagation of the heat through the bed, the rate of kerogen decomposition, and the removal of the oil from the retorting zone without serious loss.

A few in situ processes deserve special mention. One is the use of radio frequency ( $\mathrm{rf}$ ) or dielectric heating [89]. The yield is maximized because non-uniform heating of the shale bed is eliminated. Heating is slow and the final temperature achieved is less than $673 \mathrm{~K}$, which is considerably less than that attained in more conventional processes. The second process of interest is one specifically developed with low front-end costs and intended for use with very thin shale deposits [90]. This process needs improvements in rock fragmentation and oil recovery procedures. Covel1 [91] used hot gases from underground coal gasification to heat an in situ retort. The mineral components of the spent shale remove sulfur from the gases generated by the coal, thus reducing environmental problems. However, a great deal of product oil is consumed, which results in large losses in oil yield. Johnson et al. [92] have studied the thermodynamics of combined coal-oil shale processing; they are currently studying the kinetics of such processes. Fischer and Tyler [93] have used a programmed heating regime on cubes of shale in a nitrogen atmosphere. They report enhanced oil yields as a result of soaking for 24 hours at 473-573 K. 


\subsubsection{Modified in situ}

Modified in situ processes combine elements of in situ and above-ground retorting. In these a portion of the bed is mined by traditional techniques. The remaining shale is rubblized to fill the void and retorted in situ. The existence of the void volume facilitates the initiation and maintenance of the burn.

Variables which influence the yield of shale oil include the particle size heterogeneity of the rubble and fluid flow uniformity. The production of uniformly sized rubble is the principal mining problem. In addition, the pillars and the spent shale must be strong enough to give the retort stability. Control of the burn, recovery of product gas and oil, and environmental pollution remain problems, as in true in situ processes. It is most difficult to control the direction of the fracturing process to an extent that will result in a large proportion of the bed being subject to extraction procedures. Problems with insertion of spent shale into the mine are reduced because the amount that is generated that requires disposal is orders of magnitude less than that obtained in above-ground retorting.

\subsubsection{Developing processes}

For the established retorting processes, a recovery that is 65 percent of FA is normal. Some of the processes being developed have much higher oil yield or carbon conversion rates.

Hydroprocessing can be considered as treatment with 1) molecular hydrogen, particularly at elevated pressure, or 2) solvent, whether hydrogen donor or not. Processing with high-pressure hydrogen has been shown to increase oil yield for eastern U.S. shales tremendously [31] . Baldwin found solvent hydrogenation to be useful for eastern and Australian shales [94,95].

One of the processes which has been developed specifically for eastern shales is the HYTORT process, which uses a hydrogen-rich atmosphere under pressure in the retort. For Devonian shales, the yield for this process is reported to be about 200 percent of the FA yield [96]. Variables which have been examined include the effects of hydrogen partial pressure, heating rate, maximum retort temperature, and shale mass flux. Both vertical batch retorts and moving bed retorts have been considered.

The effects of high-pressure nitrogen or hydrogen depend on the geographic origin of the shale used. These processes are generally most successful with eastern U.S. shales or shales of like kerogen composition $[31,97]$. Yang and Sohn report increased oil yield at lower pressures for both Antrim and Green River shales [98].

Kahn found flash hydropyrolysis of eastern shales in a helium atmosphere to be promising [99]. Steinberg had better results with pyrolysis with methane in the system than with hydrogen or helium [100]. Carter 
summarizes studies of the effects of various parameters on fluidized-bed retorting of eastern oil shales [101]. Schadle and coworkers are using a xenon flash lamp reactor to study the energy required to generate products in a variety of shales and their organic fractions [102].

Allred [103] and Wall [104] retorted oil shale in the presence of superheated steam. Wall was able to use a low retorting temperature and removed higher quality gas readily. He attributed the increased product recovery to the fact that the product gas did not contain an inert diluent.

Supercritical extraction procedures are among the most promising of the newer processes being developed. The limited solubility of bitumen in some solvents is extended tremendously by the use of solvents in the supercritical state. When supercritical solvents are used, the conversion of organic carbon to oil and gas products increases. Chong et al. [105,106] obtained conversion of organic carbon between 70-90 percent with supercritical solvents. They looked at the effects of pressure, reaction time, and solvent systems (both subcritical and supercritical). Their most successful treatment was with supercritical methanol-water; the product was extracted with toluene-methanol. They also used pyridine on spent shale to increase the overall yield of the system. Baldwin used supercritical toluene with and without the addition of molecular hydrogen and under rapid heating conditions [107,108]. Guo used supercritical toluene and tetralin and found the extraction to proceed best at 703-723 K [109].

\subsection{Beneficiation}

Beneficiation is included as a subtopic to Processing because its use, before processing, can be effective in reducing processing costs. No entirely satisfactory beneficiation process has been developed, but efforts are being made currently to do so. This work will be facilitated by progress made in understanding the bonding that exists between mineral and organic constituents of shale.

The low ratio of organic material to mineral in shales means that little of the material actually processed has any potential for conversion to forms useful for fuels/feedstock purposes. Therefore, beneficiation processes which increase the organic content of the material to be retorted will reduce the bulk of the material that must be processed. This reduction in turn will allow 1) for smaller retorts and consequent savings in capital equipment, 2) for reduced operating costs for heating the smaller charge, and 3) for the use of alternative processing methods. In addition, problems associated with the disposal of the spent shale are reduced: there is less spent shale to be disposed of and the form in which it exists after some beneficiation processes is often less harmful to the environment.

Several methods of beneficiation have been attempted with mixed results. These include selective mining, comminution of the shale, sink-float procedures in various media, froth-flotation procedures, acid 
dissolution, and swelling with organic solvents. The success of these procedures is influenced by the grade of shale, the nature of the mineral matrix, the particle size processed, and the interaction between the mineral and organic components.

The beneficiation procedures described in the literature have been carried out on a laboratory scale rather than on a commercial scale. They were applied initially to allow for improved analyses for the richness of the shale. The need for, and benefits of, commercial scale beneficiation are discussed by Fahlstrom [110] but no results of such large scale beneficiation attempts have been described in the open literature. Earlier beneficiation studies reported have been for Green River shale [111-114]. This is probably a consequence of the common use of these procedures to improve the oil yield in the Fisher assay; Fisher assay procedures are applied most successfully to Green River shales. More recently, investigators have studied beneficiation of eastern shales [112,115-120]. Isolated studies are reported on Swedish [110], Israeli [118], and Australian [119] shales.

Selective mining of only rich shale grades will result in upgraded material, but mining in this way has often been considered to be too expensive to be practical. However, selective mining of richer shales is anticipated for utilization of eastern shales.

There is disagreement in the literature about the feasibility of separating the organic and mineral components of shale by comminution. This disagreement stems both from the nature of eastern and western shales and from uncertainty about the mode of interaction between mineral and organic species in shale $[4,9,121]$.

The gross structure of the eastern and western shales differs. In western shales, the organic and mineral components are layered; in eastern shales the particles of both components are fine-grained and are more intimately mixed in a matrix [115]. Western shales are carbonaceous and thus resistant to size-reduction on grinding as a result; the eastern shales do not contain significant amounts of carbonates and are more easily ground. Krishnan et al. note that eastern shales can be ground to 10-20 $\mathrm{m}$ in 2 hours; the carbonate-rich western shales need 8 hours [112].

Recent work has demonstrated that the interaction between the organic and mineral components is not well understood and that the bonding is such that complete separation of the two by physical means is probably impossible. For eastern shales, with their fine-grained matrix, the fines are readily separated from the larger oil-rich particles by comminution. The layered structure of the western shales makes such separation of the organic component from the inorganic more difficult. The results obtained in several beneficiation studies emphasize the difficulty of complete separation of mineral and organic components [112$13,116]$.

Comminution is used frequently in conjunction with other separation 
techniques, particularly sink-float and flotation. Reduction to $10-20 \mathrm{~m}$ has been shown to give most efficient separations [112], though Tsai and Lumpkin [120] report equally good separation at 150-500 m. Datta and Salotti [111,122] report that western shales fractured easily but eastern did not; they also report successful separation by comminution only. In this evaluation they differ from the conclusion reached by others.

Sink-float procedures in various media use the density difference of the mineral and organic components for separation. Variations of the usual gravity separation include use of heavy media [113], cyclones [111], and hydrocyclones [120]. Larson [113] notes that coarse grinding ( 3 inch top size) followed by heavy media suspension is successful in liberating increased amounts of high grade shale. However, grinding to a top size of $3 / 4$ inch or fine grinding to $45 \mathrm{~m}$ before suspension did not improve the yield.

Froth flotation procedures are based on wettability differences between the hydrophobic oil-rich material and the hydrophilic mineral matter. Flotation procedures have long been used by the metals industry in quantities of 23-91 kilotonnes/day, and thus would be expected to be good candidates for commercial separation units. Ring [123] reports that separations based on wettability differences are more successful for eastern shales than those based on gravity; neither is perfect. When gravity separation techniques are applied to eastern shales, the interaction of the water with the clay-based shales can produce a slime, which settles with extreme difficulty. Some Australian shales have been reported to produce slimes that took months to separate in settling ponds [124]. Electrostatic beneficiation methods have an efficiency equivalent to that of gravity methods. Krishnan et al. [112] have studied the effects of various surface modifying agents, temperature, and multiple flotation steps. All the surface modifying agents were equally effective. Misra et al. [125] applied froth flotation processes to eastern shales. Increases in temperature to about $335 \mathrm{~K}$ improved the separation but decreased the average shale grade; thus, operation at room temperature is favored. Yarrer and Hemphill [126] discuss an interesting variant of froth flotation procedures, which they called gamma flotation. In this, alcohols were used to alter the surface and interfacial tensions and to improve the wettability of the particles.

Reisberg [114] used the tendency of some organic liquids to be imbibed and swell the shales to induce the formation of pellets of organic phase before separating the phases. Separation was enhanced, but if the shale contained carbonates, these tended to remain attached to the oil-rich pellets. Though this procedure was successful on a laboratory scale, it is not expected to be economically feasible on a commercial scale.

McLaren [119] found that acid attack on the carbonates in Australian shales gave no improvement whatsoever. Yurum et al. [118] studied the chemical effects of acid dissolution on Israeli shales, but have not attempted to apply the process to upgrade shale quality or recovery. 


\section{KINETICS AND MODELING}

\subsection{General Considerations}

Kinetics and modeling are considered together here for two reasons.

First, a number of kinetic studies include a model, though this model is often simply a mathematical expression describing the observed kinetics; in other instances kinetic data have been used to obtain an expression which incorporates process variables, according to the more general concept of the model for a process. Second, the process models which have been developed all draw on kinetic data.

Published kinetic studies related to oil shale, most of which were intended to provide data for modeling, deal principally with the pyrolysis of the shale, with char reactions, and with mineral reactions. The need for laboratory-scale kinetic studies and subsequent modeling is particularly evident when considering in situ processing. The only practical way to estimate the effects of variables such as heating rate, particle size, or mineral content is through modeling as the nature of the in situ retort precludes true small scale experimentation. However, kinetic studies have been carried out for virtually all existing retorting configurations.

The modeling studies which have been reported for oil shale all deal with processes. No attempts to model thermal properties of shale from information about composition and heating rate have been reported. For coal, such modeling has been successful [127-130]. At the present stage of development of oil shale technology, kinetic studies make an important contribution to the improvement of processes. Better thermal property data will assist engineers in making desired improvements in process and capital equipment design.

Correlations like those proposed by Smith et al. [131] for oil yield as a function of shale grade and heating rate do exist. These are empirical, do not have the complexity normally associated with a model, and do not have the same function.

\subsection{Kinetics}

The results of the kinetic studies often appear to be contradictory. Some studies find that heating rate, particle size, or sweep gas characteristics affect kinetics; others do not. In addition, much potentially useful information is not transferable because the characterization of the shale used is so sketchy. Two papers among the many examined characterized the shales adequately $[132,133]$.

Most studies appear to have addressed one problem with a specific shale, under particular experimental conditions, once. Systematic studies of several shales, or of a whole range of conditions for one shale, are required in order to develop basic information that can be transferred to other samples or conditions. 
Two experimental techniques were used in the kinetic studies: 1) weight loss as a function of temperature or time through thermogravimetric measurements (TG); 2) rate of evolution of pyrolysis products through chromatographic measurements. In some instances, both techniques were used in a single study; the information gained from the combined studies is far superior to that obtained from one alone. Both isothermal and nonisothermal studies have been made; the range of heating rates for the nonisothermal studies reflects the range of heating rates in the various retorting processes in use. Isothermal soak periods are often used in conjunction with nonisothermal measurements; thermal induction periods compensate for finite heating times in isothermal studies.

Results are often reported in terms of intrinsic kinetics or of global kinetics; these terms need some explanation. If the system being studied is influenced only by chemical rate processes, i.e., if physical processes, such as heat and mass transfer, are unimportant, the intrinsic kinetics of the system are obtained. If, however, there are steep thermal or concentration gradients in the system, the reaction rate will be subject to heat or mass transfer limitations and the kinetics measured are not true intrinsic kinetics [134]. Smith [135] has popularized the term global reaction rate to describe those studies which include heat and mass transfer effects or unusual catalytic effects as well as the usual variables. For many of the configurations used in oil shale processing and for a material as complex as shale, global kinetics indeed seem more appropriate. It is not clear, however, that all authors using the term are using it in this sense. Some authors appear to consider the term synonymous with an overall reaction rate which replaces the individual rates describing the proposed steps in the reaction.

A detailed summary of all existing kinetic studies is not appropriate for this report. The reader who wishes such a summary will find the introductory material in several articles cited here valuable [136-140]. Many other useful references are cited by the authors whose work is considered here.

Pyrolysis studies have been carried out on large blocks of shale to aid in simulation of in situ processes [141,142], for vertical and horizontal retorting configurations [143,144], for moving [145] and fluidized beds [136,146-7], for fixed beds [148], and for various atmospheric conditions [149-151]. Heating rate, particle size, and pyrolysis temperature dependence have also been studied widely. Results reported vary from a single first-order reaction [152] to a sequence of ten specific parallel or consecutive reactions [141].

Mineral reactions, concurrent with pyrolysis reactions, complicate pyrolysis in two ways. They may be endothermic or exothermic and occur in temperature regions of concern in oil shale processing; the overlapping energies confuse the interpretation of thermal effects during pyrolysis. The kinetics of carbonate decomposition and the decomposition reactions which occur under different conditions have been studied [153] . Some mineral species, most notably calcium oxide, enhance pyrolysis through catalytic action [154]. 
The kinetics of the combustion or oxidation of char have been studied because it is the energy from these processes that supplies the energy needed for a retorting process. The effects of heating rate used in char preparation [155], char pretreatment before oxidation [156], and gasification in a steam environment have been studied for eastern [157] and western $[158,159]$ chars. Since the mineral matter reacts at temperatures at which combustion occurs, results of the char oxidation studies demonstrate vividly the sensitivity of the reactions to the presence of various minerals.

More recent studies have concentrated on the kinetics of kerogen decomposition [160] and of the oxidation of kerogen [161].

\subsection{Modeling}

Campbell et al. [162] used kinetic data from studies of a wellcharacterized shale [163] and applied the Anthony-Howard kinetic model for coal devolatilization [164] to devise a mechanism for shale pyrolysis. They suggest that a two-step process with bitumen as an intermediate occurs below $773 \mathrm{~K}$. Secondary pyrolysis above $773 \mathrm{~K}$ reduces the carbonaceous residue. Nuttall has applied three kinetic models to his data for a world-wide group of shales [165]. The simpler schemes, which assume a single first-order rate equation (Chen-Nuttall and Coates-Redfern), were not satisfactory. The Anthony-Howard model, which assumes multiple, parallel first-order reactions, gave the best correlation with experimental data. Nuttall's results demonstrate clearly that oil shales differ significantly in their thermal

decomposition behavior; consequently, different processes may be suitable for different shales. Studies that permit correlation of properties with process design are indicated.

Laboratory modeling of oil shale processes includes studies that examine the various elements of commercial processes involved in retorts, such as solids handling [96] or the effect of the variation of sweep gas concentration or rate [151]. Processes that use large chunks of shale are affected by heat transfer problems. Gregg et al. [141] have used ten chemical reactions that occur during pyrolysis, kinetic data, and a heat transfer equation to provide a model that estimates results of large-block pyrolysis well. Pan et al. [138] made several types of experimental measurements on the same shale. Unfortunately, they did not report any mineral analyses and were forced to use data for heat capacity, heat of retorting and thermal conductivity from the literature because no data more suitable to their study were available. More studies of this sort are needed.

Burnham and Braun [166] present a comprehensive mathematical model that is applicable to a wide range of pyrolysis conditions. In its formulation, it draws on a long history of measurements and model development. However, this model does not allow for concentration or thermal gradients, both of which certainly exist unless very small shale particles are used. Another drawback of this model is that data are 
drawn from the literature and are not specific to the shale used; no characterization is given. The authors do include a good analysis of things they see as weaknesses in the model and indicate that work is in progress to address some of these problems. Braun and Lewis [145] have applied a mathematical model for external combustion retorts that incorporates physical and chemical parameters. This model has proved useful for examining the effects of various retorting conditions.

The ASPEN simulator has been used widely for the simulation of a variety of industrial processes. Fong et al. [167] have applied this model to a fluidized-bed system for oil shale pyrolysis. They were particularly interested in the overall process thermal balance, the solids recirculation ratio, the effect of carbonate decomposition on heat requirements, and the sensitivity of various operating parameters on the performance of such a process. No kinetic data were included, though the model permits their use. Their emphasis was principally on combustion characteristics and the effects of these on the retorting process. Phillips et al. applied the logic of the Aspen simulator to an eastern oil shale in a HYTORT ${ }^{2}$ reactor [168].

Properties modeling, like that done for coal [127-30], would undoubtedly be of value once a satisfactory process has been developed. No record of attempts at such modeling appears in the open literature. The limited. recent attempts at modeling fluidized-bed retorts (Australia) [136] and oil shale blocks for modified in situ processes (LLNL) [141] do incorporate some of the principles involved in Merrick's approach to properties modeling. Work is under way currently at LLNL on modeling of the pyrolysis process.

\section{RECOMMENDATIONS}

Some indication of research needs for oil shale, particularly for thermophysical properties, are included in earlier sections of this report.

\subsection{General Recommendations}

The technology associated with oil shale is immature by comparison with petroleum and coal technology. The deficiencies that exist in fundamental knowledge are hampering those trying desperately to get processes to work effectively.

Since adequate characterization of shales is a prime need, it would be worthwhile to bring together a group of scientists and engineers with a variety of experience with shale to decide on what characterization information would be most useful and to suggest how best to obtain it.

Methods of measuring these properties must be selected or developed so that the information generated will be transferable. 
An agreement to concentrate research on the representative shales in existing sample banks (U.S. Geologic Survey or the Department of Energy) would extend the characterization of these shales and result in the development of a more complete data bank on which correlations can be based.

Once a satisfactory retorting process is developed, reliable and accurate thermal property data will be required in order to refine the process and scale it up for commercial production.

A survey of existing data applicable to oil shale processing and refining should be conducted; these data must be evaluated and a systematic plan for the generation of required data developed. (One reason for the success and efficiency of the petroleum industry is that it is based on extensive thermal and thermodynamic data that have been amassed through the years. Systematic efforts are under way to provide similar collections of data specific to coal and coal conversion.)

Specific needs conveyed to us by engineers and scientists with experience in processing technology include heat of retorting values and heat transfer coefficients both at retorting temperatures and at the temperatures expected in the combustor. This information is required as a function of heating rate, of ambient atmospheres, of pressure, and of shale composition (organic and mineral and different ratios of aliphatic and aromatic species). It is needed for raw, spent, and burnt shale, for kerogen, and for the individual minerals found in shale. The retorted shale should be prepared under different, but potentially realizable, conditions to generate realistic mixtures of components.

The kerogen should be separated as completely as possible from the mineral components of shale and the properties of kerogen determined. Then mineral species in realistic proportions should be added one by one and the (kerogen + mineral) properties redetermined. The effects of the minerals and mineral interactions can be evaluated only through such a systematic study.

A computer program that predicts the most probable mineral reactions should be activated to identify the species most likely to exist.

Other needs that exist include heats of reaction of the mineral species present in shales; heat capacities and enthalpies of raw, spent and burnt shale; thermal conductivity; heat transfer coefficients; enthalpies of hydration and dehydration of minerals with significant clay components. (Heat capacity data exist for many pure minerals. At temperatures at which there is no possibility for solid state reactions, heat capacities and enthalpies of minerals are additive. At higher temperatures, like those involved in the combustor, reactions occur and the additive relationship can no longer be used. As thermal conductivity is required 
for those same species, additivity relationships for this property must be explored.)

A systematic comparison of heats of combustion of well-characterized shales, including demineralized shales, by static and rotating bomb calorimetry should be made.

Modifications of our coal model that will make it applicable to shale should be investigated. It could provide the capability for modeling heat capacity, thermal conductivity, thermal expansion, and heat transfer. This modeling requires systematic studies of thermal properties of shale as opposed to the isolated studies that have been reported.

Problems mentioned to us often, but largely outside the intended scope of this report, include those associated with solids handling and mechanical problems and those leading to an understanding of the interactions between mineral and organic components of shale. The abrasive nature of oil shale results in the production of large quantities of fines, which seriously affect the performance of retorts, particularly with regard to the propagation of heat and products. As rich shales tend to produce more fines than lean shales, this problem is especially serious for the rich shales. In addition, flow channeling in retorts can limit oil yields severely. Abrasion and mechanical properties should be studied as functions of pertinent variables outlined above.

\subsection{Specific Recommendations}

1. Complete a quantitative evaluation of existing thermophysical property data.

2. Develop procedures for the measurement of the heat of retorting of raw shale if a suitable calorimeter is acquired or constructed.

3. Develop reliable procedures for measuring thermal properties of raw, retorted, and burnt shale from room temperature to $973 \mathrm{~K}$.

Measurements on raw shale will be confined to temperatures below and above the region where reactions are occurring. This temperature region will vary according to the shale used, particularly its mineral content. Properties of interest here include heat capacity, thermal conductivity (thermal diffusivity), and perhaps, thermal expansion. For these procedures, a first step will be to evaluate the procedures already developed for other solid fuels/feedstocks when used with shale.

4. While verifying the validity of these procedures, they should be applied to a wide range of shales. This will help to ensure that problems like those related to the FA of eastern shales will be eliminated or compensated for.

5. Develop a satisfactory modeling capability for the thermal properties of shale. A first effort here could well be adaptation of the logic contained in the program we use for coal. 
6. Support the experimental requirements of the modeling effort by conducting in-house research and by coordinating research in industry and academia.

7. Attempt to develop a satisfactory measurement procedure for the heat of immersion of spent shale in various media (water, hydrocarbon liquid).

8. Explore possible connections between various processing treatments and the thermal properties of the materials that result.

9. Evaluate the effects of various atmospheres on thermal properties.

10. Survey existing thermodynamic data for model compounds for oil shale.

11. Select model compounds appropriate to shale and measure properties, especially thermodynamic.

12. Coordinate projects with industrial and academic research centers to provide expanded expertise and experimental facilities.

13. Activate and adapt an existing adiabatic calorimeter to an in-house study of heat capacity of model compounds. 


\section{REFERENCES}

[1] Callanan, J. E. Review of needs for thermophysical property data on solid feedstocks. I. Coal. NBSIR 82-1666; 1982 May. 25 p.

[2] Yen, T. F. Structural investigations on Green River oil shale kerogen. in Science and technology of oil shale. T. F. Yen, ed. Ann Arbor, MI: Science Publishers; 1976. 193-203.

[3] Blatt, H.; Middleton, G.; Murray, R. Facies models. Origin of sedimentary rocks, 2nd ed. Englewood Cliffs, NJ: Prentice-Hall, Inc.; 1980. Chapter 19.

[4] McKay, J. F. A discussion of the chemical structure of the organic matter in Green River oil shale. Energy Sources 7: 257-270; 1984.

[5] Tissot, B. P.; Vandenbroucke, M. Geochemistry and pyrolysis of oil shales. ACS Symposium Series 230: 1-12; 1983.

[6] Tissot, B.; Durand, B. ; Espitalie, J.; Combaz, A. Influence of nature and diagenesis of organic matter in formation of petroleum. Am. Assoc. Petrol. Geol. Bull. 58: 499-506; 1974.

[7] Philp, R. P. Recent studies on the origin and structure of possible kerogen-precursors. in $0 i l$ sand and oil shale chemistry. 0. P. Strausz and E. M. Lown, eds. NY: Verlag Chemie; 1978. 325-344.

[8] Mason, G. M. Minerology of the Mahogany Marker tuff of the Green River formation, Piceance Creek Basin, Colorado. Gary, J. H., ed. Proceedings of the 16th Oil Shale Symposium; 1983 April 13-15; Golden, CO. Colorado School of Mines; 1983 August. 124-131.

[9] Jeong, K. M.; Kobylinski, T. P. Organic-mineral matter interactions in Green River oil shale. ACS Symposium Series 230: 493-512; 1983.

[10] Espitalie, J.; Madec, M.; Tissot, B. Role of mineral matrix in kerogen pyrolysis: Influence on petroleum generation and migration. Am. Assoc. Petrol. Geol. Bull. 64: 59-66; 1980.

[11] Ranney, M. W. Oil shale and tar sands technology. Recent developments. Park Ridge, NJ: Noyes Data Corporation; 1979.

[12] Duncan, D. C.; Swanson, V. E. Organic-rich shale of the United States and world land areas. U. S. Geological Survey Circular 523. 1965. $30 \mathrm{p}$.

[13] Smith, J. W. Oil shale resources of the United States. Mineral and Energy Resources 23(6): 1-20; 1981 . 
[14] Baker, J. D.; Hook, C. O. Chinese and Estonian oil shale. Gary, J.H., ed. Proceedings of the 12th 0il Shale Symposium; 1979 April 18-20; Golden, CO. Colorado School of Mines Press. 1979 August. $26-31$.

[15] Janka, J. C.; Dennison, J. M. Devonian oil shale - a major American energy resource. IGT Symposium on Synthetic Fuels from 0il Shale. 1979 Dec. 3-5; Atlanta, Ga. 1980 April. 21-116.

[16] Matthews, R. D.; Feldkirchner, H. Devonian oil shales in the Eastern United States. Distribution and regional correlation. ACS Symposium Series 230: 139-157; 1983.

[17] 1983 Annual book of ASTM standards. ASTM Standard Test Method D 3904-80. Standard test method for oil from oil shale (Resource evaluation by the USBM Fischer Assay procedure). Section 5. Petroleum products, lubricants, and fossil fuels. Vol. 5.03. Petroleum products and lubricants (III): D2491 - latest; Catalysts. Philadelphia, PA: American Society for Testing and Materials; 1984.

[18] Rubel, A. M.; Coburn, T. T. Influence of retorting parameters on oil yield from Sunbury and Ohio oil shales from northeast Kentucky. Proceedings of the Eastern Oil Shale Symposium; 1981 Nov. 15-17; Lexington, KY. 1981; 21-30.

[19] 1983 Annual book of ASTM standards. Section 5. Petroleum products, lubricants, and fossil fuels. Vol. 5.05. Gaseous Fuels; Coal and Coke. Philadelphia, PA: American Society for Testing and Materials; 1983.

[20] Cox, J. L., ed. 1981 Proceedings of DOE/GRI Coal Sample Bank Workshop, Atlanta, GA. March 27-28. (Springfield, VA: National Technical Information Service), publication PB 82-243841.

[21] Stanfield, K. E. ; Frost, I. C.; McAuley, W. S.; Smith, H. N. Properties of Colorado oil shale. Bur. Mines RI 4825. 1951. 27p.

[22] Smith, J. W.; Young, N. B. Determination of dawsonite and nahcolite in Green River Formation oil shales. Bur. Mines RI 7286. 1969. 20 .

[23] Nadkarni, R. A. Characterization of oil shales. ACS Symposium Series 230: 477-492; 1983.

[24] Fischer, F.; Schrader, H. Bestimmungen mit einen Aluminum-schwelapparat. Z. angew. Chem. 33: 172-175; 1920.

[25] Stanfield, K. F.; Frost, I. C. Method of assaying oil shale by a modified Fischer retort. Bur. Mines RI 3977. 1946. 11p. 
[26] Stanfield, K. F.; Frost, I. C. Method of assaying oil shale by a modified Fischer retort. Bur. Mines RI 4477. 1949. 13p. (Revision of Bur. Mines RI 3977).

[27] Smith, J. W. Analytical method for study of thermal degradation of oil shale. Bur. Mines RI 5932. 1962. 17p.

[28] Hubbard, A. B. Automated modified Fischer retorts for assaying oil shale and bituminous materials. Bur. Mines RI 6676. 1965. 19p.

[29] Goodfellow, L; Haberman, C. E.; Atwood, M. T. Modified Fischer assay-Equipment, procedures and product balance determinations. Paper presented before Div. of Petroleum Chemistry. ACS National Meeting. San Francisco, CA. 1968 April.

[30] Goodfellow, L.; Atwood, M. Fischer assay of oil shale. Procedures of The Oil Shale Corporation. Gary, J. H., ed. Proceedings of the 7 th $0 i 1$ Shale Symposium; 1974 April 18-19; Golden, CO. Colorado School of Mines Press. 1974 Aug. 205-219.

[31] Lynch, P. A.; Janka, J. C.; Lau, F. S.; Feldkirchner, H. L.; Dirksen, H. A. The hydroretorting assay - A new technique for oil shale assessment. Fuel Div. ACS Preprints 29 (3): 71-75; 1984.

[32] Audeh, C. A. Rapid heat-up assay for eastern oil shales. Fuel Div. ACS Preprints 29 (3): 19-25; 1984.

[33] Rube1, A. M. ; Margolis, M. J.; Haley, J. K.; Davis, B. H. Bench scale fluid bed retorting of Kentucky oil shale. Proceedings of the 1983 Eastern Oil Shale Symposium; 1983 Nov. 13-16; Lexington, KY. 1983. 399-405.

[34] Margolis, M. J.; Taulbee, D. N. ; Rubel, A. M. ; Howard, J. I. Analytical pyrolysis evaluation of the retorting potential of Kentucky oil shale. Fuel Div. ACS Preprints 29 (3): 76-87; 1984.

[35] Rube1, A.M.; Audeh, C.A. Comparison of product yields obtained from the New Albany shale by different rapid heating retorting procedures. Proceedings of the Eastern Oil Shale Symposium; 1984 Nov. 26-28; Lexington, KY. 1984; 83-90.

[36] Espitalie, J.; Madec, M.; Tissot, B.; Mennig, J. J. Paper presented at the Offshore Technology Conference Houston, TX. Preprint OTC 2935. 1977 439-444.

[37] Miknis, F. P. Current methods of oil shale analysis and new developments (NMR). IGT Symposium on Synthetic Fuels from 0il Shale. 1979 Dec. 3-5; Atlanta, Ga. 1980 April. 245-269.

[38] Netzel, D. A. High-resolution NMR spectroscopy: Its application to shale oil component/type analysis. IGT Symposium on Synthetic Fuels from Oil Shale. 1979 Dec. 3-5; Atlanta, Ga. 1980 April. 271-304. 
[39] Miknis, F. P.; Decora, A. W.; Cook, G. L. Pulsed nuclear magnetic resonance examination of oil shales. Bur. Mines RI 7984. 1974.

$47 \mathrm{p}$.

[40] Maciel, G. E.; Bartuska, V. J.; Miknis, F. P. Improvement in correlation between oil yields of oil shales and $13 \mathrm{C}$ NMR spectra. Fue1 57: 505-506; 1978. Fue1 58; 155-156; 1979.

[41] Trewhe11a, M. J.; Poplett, I. J. F.; Grint, A. Structure of Green River oil shale kerogen. Fuel 65: 541-546; 1986.

[42] Rajeshwar, K.; Jones, D. B.; DuBow, J. B. Characterization of oil shales by differential scanning calorimetry. Anal. Chem. 53: 121$122 ; 1981$.

[43] Johnson, D. R.; Smith, J. W. ; Young, N. B. Stratigraphic variation of oil shale enthalpy of retorting through the Green River formation of the Colorado C-a tract. Laramie Energy Technology Center RI 79/9. 1979. 16p.

[44] Johnson, D. R.; Smith, J. W. Bureau of Mines apparatus for thermal analysis: simultaneous DTA-TG-EGA for oil shale and solid fuels. Bur. Mines RI 7429. 1970. 17 p.

[45] Johnson, D. R.; Young, N. B.; Smith, J. W. Thermal analysis on oil shale: determination of potential oil yields and dawsonite, nahcolite, and nordstrandite content. Laramie Energy Technology Center RI 77/6 1977. $18 \mathrm{p}$.

[46] Judzis, A., Jr.; Williams, B.; Hiatt, R. E. Assaying Green River oil shale with microwave radiation. Gary, J. H., ed. Proceedings of the 10th Oil Shale Symposium; 1977 April 21-22; Golden, CO. Colorado School of Mines Press. 1977 August. 207-212.

[47] Jesch, R. L. ; McLaughlin, R. H. Dielectric Measurements of oil shale as functions of temperature and frequency. NBSIR 83-1683. 1983. $31 \mathrm{p}$.

[48] Jesch, R. L.; McLaughlin, R. H. Dielectric Measurements of oil shale as functions of temperature and frequency. IEEE Transactions on Geoscience and Remote Sensing GE22: 99-105; 1984.

[49] Neave1, R. C.; Hippo, E. J.; Smith, S. E.; Miller, R. N. Coal characterization research: sample selection, preparation, and analysis. Fuel Div. ACS Preprints 25 (3): 246-257; 1980.

[50] Kirov, N. Y. Specific heats and total heat contents of coals and related materials at elevated temperatures. BCURA Month1y Bul1., Rev. 241, 29: 33-59; 1965. 
[51] Callanan, J. E.: Sullivan, S. A. Development of standard operating procedures for differential scanning calorimeters. Rev. Sci. Instr. 57: $2584-2592 ; 1986$.

[52] O'Hare, P. A. G. Argonne National Laboratory, Argonne, IL 60439. Private communication.

[53] 1983 Annual book of ASTM standards. D 2015-77. Standard test method for gross calorific value of solid fuel by the adiabatic bomb calorimeter. Section 5. Petroleum products, lubricants, and fossil fuels. Vol. 5.05. Gaseous Fuels; Coal and Coke. Philadelphia, PA: American Society for Testing and Materials; 1983.

[54] 1983 Annual book of ASTM standards. D 3286-82. Standard test method for gross calorific value of solid fuel by the isothermal-jacket bomb calorimeter. Section 5. Petroleum products, lubricants, and fossil fuels. Vol. 5.05. Gaseous Fuels; Coal and Coke.

Philadelphia, PA: American Society for Testing and Materials; 1983.

[55] Steele, W. V. NIPER, P. 0. Box 2128, Bartlesville, OK 74005. Private communication.

[56] Boston, J., Department of Chemical Engineering, MIT, Cambridge, MA 02139. Private communication.

[57] Muehlbauer, M.J.; Burnham, A.K. Heat of combustion of Green River oil shale. Ind. Eng. Chem. Process Des. Dev. 23: 234-236; 1984.

[58] Burnham, A.K.; Crawford, P.C.; Carley, J.F. Heat of combustion of retorted and burnt Colorado oil shale. Ind. Eng. Chem. Process Des. Dev. 21: 485-489; 1982 .

[59] Crawford, P. C.; Orvellas, D. L.; Lum, R. C.; Johnson, P. G. Combustion calorimetry of oil shales. Lawrence Livermore National Laboratory. Preprint UCRL-81285. Oct. 19, 1978.

[60] Turnbul1, A. G.; Corino, G. L. Pyrolysis and combustion studies of Australian oil shales by D.S.C. methods. Paper \#144 presented at IUPAC Conference on Chemical Thermodynamics/39th Calorimetry Conference. 1984 August 13-17. Hamilton, Ontario, Canada.

[61] Corino, G. L.; Turnbull, A. G. Calorimetric studies of oil shales and shale products. Proceedings of 2nd Australian Workshop on 0il Shale, 1984 Brisbane. 97-102.

[62] Mraw, S. C.; Keweshan, C. F. Calorimetric determination of the heats of retorting Green River and Rundle oil shales to $500{ }^{\circ} \mathrm{C}$ and of the heat of combustion of spent Green River shale at $705{ }^{\circ} \mathrm{C}$. Fuel Div. ACS Preprints 30 (3): 324-331; 1985. 
[63] Mraw, S. C.; Keweshan, C.F. Calorimetric determination of the heat of combustion of spent Green River shale at $978 \mathrm{~K}\left(705^{\circ} \mathrm{C}\right)$. Paper presented at the 4lst Calorimetry Conference. 1986 August 17-22. Somerset, NJ .

[64] Ringen, S.; Lanum, J.; Miknis, F. P. Calculating heating values from elemental compositions of fossil fuels. Fuel 58: 69-71; 1979.

[65] Boie, W. Beitrage zum feuerungstechnischen Rechnen.

Wisssenschaftliche Zeitschrift der Technischen Hochschule Dresden 2: $687-718 ; 1952 / 53$.

[66] Smith, J. W.; Young, N. B. Organic composition of Kentucky's New Albany shale: determination and uses. Chem Geol. 2: 157-170; 1967.

[67] Smith, J. W. Ultimate composition of organic material in Green River oil shale. Bur. Mines RI 5725. 1961. 16p.

[68] Shaw, R. J. Specific heat of Colorado oil shales. Bur. Mines RI 4151. 1947. 9 p.

[69] Sohns, H. W.; Mitche11, L. E.; Cox, R. J.; Barnet, W. I. ; Murphy, W. I. R. Heat requirements for retorting oil shale. Industrial and Engineering Chemistry 43: 33-36; 1951.

[70] Wise, R. L.; Miller, R. C.; Sohns, H. W. Heat contents of some Green River oil shales. Bur. Mines RI 7482. 1971. 16p.

[71] Calvet, E. Experimental thermochemistry. Rossini, F. D., ed. New York: Interscience Publishers; 1956. 237-286.

[72] Mraw, S. C.; Keweshan, C. F.; Calvet-type calorimeter for the study of high-temperature processes. II. New ballistic method for the enthalpy of vaporization of organic materials at high temperatures. $\mathrm{J}$. Chem. Thermodynamics 16: 873-883; 1984 .

[73] Mraw, S. C.; Kleppa, O. J. Calvet-type calorimeter for the study of high-temperature processes. I. Description of an apparatus appropriate for organic materials. J. Chem. Thermodynamics 16: $865-871 ; 1984$.

[74] Mraw, S. C.; Keweshan, C. F. New calorimetric method for vaporization processes at high temperature: Liquid fractions and raw oil shale. Ind. Eng. Chem. Fundam. 24: 269-271; 1985.

[75] Mraw. S. C.; Keweshan, C. F. Calorimetric determination of the heat of retorting of oil shales to $773 \mathrm{~K}$. Fuel 65: 54-57; 1986.

[76] Carley, J. F., Lawrence Livermore National Laboratory. Livermore, CA. 94550. Private communication. 
[77] Camp, D. W., Lawrence Livermore National Laboratory. Livermore, CA, 94550. Private communication.

[78] Singer, J. M.; Tye, R. P. Thermal, mechanical, and physical properties of selected bituminous coals and cokes. Bur. Mines RI 8364. 1979. 37p.

[79] Gavin, M. J.; Sharp, L. H. Some physical and chemical data on Colorado oil shale. Bur Mines RI 2152. 1920. 8p.

[80] Taylor, R. E.; Groot, H. Thermophysical properties of geologic materials. Hust, J. G., ed. Thermal Conductivity 17: 611-618. New York: Plenum Press; 1983.

[81] Gilliam, T. M.; Morgan, I. L. Thermal properties of eastern shale. Proceedings of the Eastern Oil Shale Symposium; 1985 Nov. 18-20; Lexington, KY. 1985; 207-214.

[82] Tihen, S. S. Carpenter, H. C.; Sohns, H. W. Thermal conductivity and thermal diffusivity of Green River oil shale. Flynn, D. R.; Peavvy, B. A.,Jr., eds. Thermal Conductivity 7: 529-535. NBS Special Publication 302. 1968.

[83] Nottenburg, R.; Rajeshwar, K.; Rosenfold, R.; DuBow, J. Measurement of thermal conductivity of Green River oil shales by a thermal comparator technique. Fuel 57: 789-795; 1978.

[84] Smith, J.W.; Johnson, D. R. Mechanisms helping to heat oil shale blocks. Fuel Div. ACS Preprints 21 (6): 25-33; 1976.

[85] Duval1, F. E. W. ; Sohn, H. Y.; Pitt, C. H. Bronson, M. C. Physical behavior of oil shale at various temperatures and compressive loads: 1. Free thermal expansion. Fue1 62: 1455-1461; 1983.

[86] Smith, J.W. Specific gravity; oil yield relationships of two Colorado oil shale cores. Ind. Eng. Chem. 48: 441-444; 1956.

[87] Khan, M. R.; Jenkins, R. G. Thermoplastic properties of coal at elevated pressures. 1. Evaluation of a high-pressure microdilatometer. Fuel 63; 109-115; 1984.

[88] Khan, M. R. A parametric study of thermophysical properties of oil shale. Fuel (in press).

[89] Gould, G. D.; McKinsey, R. R.; Bridges, J. E.; Sresty, G. In situ retorting via RF heating. Gary, J. H., ed. Proceedings of the 17 th Oil Shale Symposium; 1984 April 16-18; Golden, CO. Colorado School of Mines; 1984 August. 37-45. 
[90] Lekas, M. A. Progress report on the Geokinetics horizontal in situ retorting process. Gary, J. H., ed. Proceedings of the 12 th 0 il Shale Symposium; 1979 April 18-20; Golden, CO. Colorado School of Mines; 1979 August. 228-236.

[91] Covell, J. R. ; Fahy, J. L.; Schreiber, J.; Sudduth, B. C.; Trudall, L. Indirect in situ retorting of oil shale using the TREE(sm) process. Gary, J. H., ed. Proceedings of the 17 th $0 i 1$ Shale Symposium; 1984 April 16-18; Golden, CO. Colorado School of Mines; 1984 August. 46-58.

[92] Johnson, L.; Rostam-Abadi, M. ; Mirza, I.; Stephenson, M. ; Kruse, C. Copyrolysis of coal and oil shale I. Thermodynamics and kinetics of $\mathrm{H}_{2} \mathrm{~S}$ capture by oil shale. Fuel Div. ACS Preprints 30(3): 274-285; 1985.

[93] Fischer, P. E.; Tyler, A. L. The effect of programmed heating on the rate of oil production from Green River oil shales. In Situ 9: $25-51 ; 1985$.

[94] Baldwin, R. M.; Briley, R. A.; Baughman, G. L.; Minden, C. S . Hydro-processing of Kentucky oil shale. Eastern Oil Shale Symposium; 1983 November 13-16; Lexington, KY. 1983. 333-336.

[95] Baldwin, R. M.; Bennett, D. P.; Briley, R. A. Reactivity of oil shale toward solvent hydrogenation. Fuel Div. ACS Preprints 29 (3): $148-153 ; 1984$.

[96] Rex, R.C., Jr.; Janka, J.C.; Knowlton, T.M.; Cold flow model testing of the HYTORT process retort design. Gary, J.H., ed. Proceedings of the 17th Oil Shale Symposium; 1984 April 16-18; Golden, CO. Colorado School of Mines Press. 1984 August. 17-36.

[97] Ekstrom, A.; Fookes, C. J. R.; Wong, K. The retorting of selected Australian oil shales under high pressure hydrogen and nitrogen. Fuel Div. ACS Preprints 30 (3): 301-308; 1985.

[98] Yang, H.S.; Sohn, H.Y. Effects of reduced pressure on oil shale. 2. Oil yield. Ind. Eng. Chem. Process Des. Dev. 24: 271-273; 1985.

[99] Kahn, D.R.; Falk,A.Y.; Garey, M.P. Flash hydropyrolysis of eastern oil shale. Proceedings of the Eastern Oil Shale Symposium; 1983 Nov. 13-16; Lexington, KY. 1983; 299-309. 
[100] Steinberg, M.; Fallon, P. T. Flash pyrolysis of oil shale with various gases. Fuel Div. ACS Preprints 29 (3): 217-223; 1984.

[101] Carter, S.D. Status of fluidized-bed research. Proceedings of the Eastern 0il Shale Symposium; 1985 Nov. 18-20; Lexington, KY. $1985 ; 35-38$.

[102] Shadle, L.J.; Gaston, M.H.; Rosencrans, R. Pyrolysis of oil shale in a flash lamp reactor. Proceedings of the Eastern Oil Shale Symposium; 1985 Nov. 18-20; Lexington, KY. 1985; 185-194.

[103] Allred, V. D. Considerations for retorting oil shales with superheated water vapor. Gary, J. H., ed. Proceedings of the 12th Oil Shale Symposium; 1979 April 18-20; Golden, CO.

Colorado School of Mines; 1979 August. 241-251.

[104] Wall, G. C. Isothermal fluidised-bed pyrolysis of Australian oil shales in superheated steam. Gary, J. H., ed. Proceedings of the 17th Oil Shale Symposium; 1984 April 16-18; Golden, CO. Colorado School of Mines; 1984 August. 300-309.

[105] Chong, S-L.; McKay, J. F. Investigation of organic products from the thermal treatment of Green River oil shale with methanol and water. Fuel Div. ACS Preprints 29 (3): 26-33; 1984 .

[106] Chong, Y. O.; Nicklin, D. J.; Tait, P. J. A new oil shale retort. Fluid beds exchanging solids but not gases. Gary, J. H., ed. Proceedings of the 18 th oil shale symposium; 1985 April 22-24; Golden, CO. Colorado School of Mines; 1985 August. 155-161.

[107] Baldwin, R. M.; Lane, G. S.; Chen, K. W. Pyrolysis of oil shale in supercritical toluene. Gary, J. H., ed. Proceedings of the 18th Oil Shale Symposium; 1985 April 22-24; Golden, CO. Colorado School of Mines; 1985 August. 176-181.

[108] Baldwin, R. M.; Manley, J. A. Pyrolysis and hydropyrolysis of Kentucky oil shale in supercritical toluene under rapid heating conditions. Fuel Div. ACS Preprints 30 (3): 309-315; 1985.

[109] Guo, S-C.; Wei, H.; Huang, G-W.; Hu, H-Q.; Rui, W.; Hedden, K. ; Wilhelm, A. Conversion of Chinese oil shales to liquid products using supercritical extraction. Erdol \& Kohle, Erdgas

Petrochemie 39: 311-316; 1986.

[110] Fahlstrom, P. H. A physical concentration route in oil shale winning. Gary, J. H., ed. Proceedings of the 12th Oil Shale Symposium; 1979 April 18-20; Golden, CO. Colorado School of Mines; 1979 August. 252-277. 
[111] Datta, R. S.; Salatti, C. A. Coarse beneficiation of Green River oil shale. Gary, J. H., ed. Proceedings of the 16th 0il Shale Symposium; 1983 April 13-15; Golden, CO. Colorado School of Mines; 1983 August. 413-425.

[112] Krishnan, G. N.; Farley, E. P.; Murray, R. G. Beneficiation of U. S. oil shales by froth flotation. Gary J. H., ed.

Proceedings of the 6th 0il Shale Symposium; 1983 April 13-15; Golden, CO. Colorado School of Mines; 1983 August. 426-436.

[113] Larson, O. A.; Schultz, C. W. ; Michaels, E. L. Beneficiation of Green River oil shales by density methods. Stauffer, H. C., ed. ACS Symposium Series 163(10): 136-154; 1981.

[114] Reisberg, J. Beneficiation of Green River oil shale by pelletization. Stauffer, H. C., ed. ACS Symposium series 163(11): $155-166 ; 1981$.

[115] Audeh, C. A. Beneficiation of water-sensitive Eastern oil shales. Fuel Div. ACS Preprints 30(3): 229-236; 1985.

[116] Tippin, R. B.; Rex, R. G. Combined beneficiation and hydroretorting of oil shale. Fuel Div. ACS Preprints 30 (3): 237-246; 1985.

[117] Parkinson, G. New ways to process oil shale. Chemical Eng.: $37-43$; 1982 February 22.

[118] Yurum, Y.; Dror, Y.; Levy, M. Effect of acid dissolution on the mineral matrix and organic matter of Zeta Efe oil shale. Fuel Processing Technology 11: 71-86; 1985.

[119] McLaren, K. G. Kerogen-mineral bonding and beneficiation studies with a carbonate oil shale, using carbonic acid attack and a novel explosive disintegration technique. Fuel Processing Technology 10: 163-168; 1985.

[120] Tsai, S. C.; Lumpkin, R. E. Oil shale beneficiation by froth flotation. Fuel 63: 435-439; 1984.

[121] Jeong, K. M.; Kobylinski, T. P. Organic-mineral matter interactions in Green River oil shale. Fuel Div. ACS Preprints 28 (3): $209-219 ; 1983$.

[122] Datta, R. S.; Salotti, C. A. Beneficiation of Eastern oil shale. Proceedings of the Eastern 0il Shale Symposium; 1982 October 11-13; Lexington, KY. 227-234.

[123] Ring, T. A. Mineral beneficiation of oil shale. Proceedings of the Eastern oil shale symposium; 1981 November 15-17; Lexington, KY. 305-310. 
[124] James R. Burchfield, Morgantown Energy Technology Center, Morgantown, WV. 26505. Private communication.

[125] Misra, M.; Lin, C. L.; Miller, J. D. Concentration of Eastern oil shales by froth flotation. Proceedings of the Eastern 0il Shale Symposium; 1983 November 13-16; Lexington, KY. 1983. 377-387.

[126] Yarar, B.; Hemphil1, G. P. Use of critical surface tension of wetting in the beneficiation of oil shales: Gamma flotation. Gary, J. H., ed. Proceedings of the 17th 0il Shale Symposium; 1984 April 16-18; Golden, CO. Colorado School of Mines; 1984 August. 433-440.

[127] Merrick, D. Mathematical models of the thermal decomposition of coal: 2. Specific heats and heats of reaction. Fuel 62: $540-546 ; 1983$.

[128] Merrick, D. Mathematical models of the thermal decomposition of coal: 3. Density, porosity, and contraction behavior. Fuel 62: $547-552 ; 1983$.

[129] Merrick, D. Mathematical models of the thermal decomposition of coal: 4. Heat transfer and temperature profiles in a coke-oven charge. Fue1 62: 553-561; 1983.

[130] Callanan, J. E.; Sullivan, S. A.: MacDonald, R. A. Experimental determination and modeling of the heat capacity of coal in various atmospheres. Intl. J. Thermophys. 8: 133-145; 1987.

[131] Smith, J. W. Conversion constants for Mahogany Zone oil shale. Am. Assoc. Petrol. Geo1. Bul1. 50: 167-170; 1966.

[132] Burnham, A. K.; Stubblefield, C. T.; Campbell, J. H. Effects of gas environment on mineral reaction in Colorado oil shale. Fue1 59: 871-877; 1980.

[133] Burnham, A. K.; Huss, E. B.; Singleton, M. F. Pyrolysis kinetics for Green River oil shale from the saline zone. Fuel 62; 1199-1204; 1983 .

[134] Hill, C. G., Jr. An introduction to chemical engineering kinetics and reactor design. New York: John Wiley \& Sons; 1977. Chap. 3, 12 .

[135] Smith, J. M. Chemical engineering kinetics, 2nd. ed. New York: McGraw Hil1; 1970.

[136] Wallman, P. H.; Tammm P. W.; Spars, B. G. Oil shale retorting kinetics. ACS Symposium Series 163: 93-113; 1983. 
[137] Wang. C-C.; Noble, R. D. Composition and kinetics of oil generation from non-isothermal oil shale retorting. Fuel 62; $529-533 ; 1983$.

[138] Pan, Z.; Feng, H. Y.; Smith, J. M. Rates of pyrolysis of Colorado oil shale. AIChE Journal 31; 721-728; 1985.

[139] Yang, H. S.; Sohn, H. Y. Kinetics of oil generation from oil shale from Liaoning province of China. Fuel 63; 1511-1514; 1984 .

[140] Charlesworth, J. M. Oil shale pyrolysis 2. Kinetics and mechanism of hydrocarbon evolution. Ind. Eng. Chem. Process Des. Dev. 24: 1125-1132; 1985.

[141] Gregg, M. L. ; Campbell, J. H. ; Taylor, J. R. Laboratory and modeling investigation of a Colorado oil shale block heated to $900{ }^{\circ} \mathrm{C}$. fuel 60 : $179-188 ; 1981$.

[142] Shih, S-M. Lumped-parameter model for the retorting of a large block of oil shale with an internal temperature gradient. Fuel $62 ; 746-748 ; 1983$.

[143] Carley, J. F.; Thigpen, L. Modeling of vertical pressure distribution in large in-situ retorts. Gary, J. H., ed. Proceedings of the 10th Oil Shale Symposium; 1977 April 21-22; Golden, CO. Colorado School of Mines Press. 1977 August. $180-190$.

[144] Charlesworth, J. M. Oil shale pyrolysis. 1. Time and temperature dependence of product composition. Ind. Eng. Chem. Process Des. Dev. 24: 1117-1125; 1985.

[145] Braun, R. L.; Lewis, A. E. Results of mathematical modeling of oil shale retorting in an above-ground, external-combustion, moving-bed retort. Gary, J. H., ed. Proceedings of the 18th 0 il Shale Symposium; 1985 April 22-24; Golden, CO. Colorado School of Mines Press. 1985 Aug. 133-143.

[146] Braun, R. L.; Burnham, A. K. Kinetics of Colorado oil shale pyrolysis in a fluidized-bed reactor. Fuel 65; 218-222; 1986.

[147] Richardson, J. H. ; Huss, E. B. Fluidized-bed pyrolysis of oil shale. Fuel Div. ACS Preprints 27(2): 173-186; 1982.

[148] Knight, J. H.; Fishback, J.W. Superior's circular grate oil shale retorting process and Australian Rundle oil shale process design. Gary, J.H., ed. Proceedings of the 12 th Oil Shale Symposium; 1979 April 18-20; Golden, CO. Colorado School of Mines; 1979 August. 1-16. 
[149] Polasky, M. E.; Lee, S. Pyrolysis kinetics of various Australian oil shales in nitrogen and carbon dioxide atmospheres. Fuel Div. ACS Preprints 30(3): 294-300; 1985.

[150] Noble, R. D.; Harris, H. G.; Tucker, W. F. Isothermal oil shale pyrolysis. 2. Kinetics of product formation and composition at various pressures. Fuel 60; 573-576; 1981.

[151] Braun, R. L.; Chin, R. C. Y. Computer model for in-situ oil shale retorting; Effects of gas introduced into the retort. Gary, J. H., ed. Proceedings of the 10th 0il Shale Symposium; 1977 April 21-22; Golden, CO. Colorado School of Mines Press. 1977 August. $166-179$.

[152] Shih, S.-M., Sohn, H. Y. Nonisothermal determination of the intrinsic kinetics of oil generation from oil shale. Ind. Eng. Chem. Process Des. Dev. 19: 420-426; 1980.

[153] Campbe11, J. H.; Burnham, A. K. Oil shale retorting: Kinetics of the decomposition of carbonate minerals and subsequent reaction of $\mathrm{CO} 2$ with char. Gary, J. H., ed. Proceedings of the 11th Oil Shale Symposium; 1978 April 12-14; Golden, CO. Colorado School of Mines Press. 1978 August. 242-259.

[154] Allred, V. D., ed. Oil shale processing technology. East Brunswick, NJ: Center for Professional Advancement; 1982.

[155] Burnham, A. K. Reaction between $\mathrm{CO} 2$ and oil-shale residual carbon. 1. Effects of heating rate on reactivity. Fuel 58: $285-292 ; 1979$.

[156] Burnham, A. K. Reaction kinetics between $\mathrm{CO} 2$ and oil-shale residual carbon. Fue1 58: 713-718; 1979.

[157] Van Tuy1, D. E.; Thomson, W. J. Reaction kinetics of the gasification of Michigan Antrim oil shale char. Fuel 65: $58-62 ; 1986$.

[158] Burnham, A. K. Reaction kinetics between steam and oil-shale residual carbon. Fue1 58; 719-723; 1979.

[159] Thomson, W. J.; Gerber, M. A.; Hatter, M. A.; Oakes, D. G. Kinetics of oil shale char gasification. ACS Symposium Series 163: $115-127$; 1981.

[160] Natarajan, M. Kinetic studies on kerogen decomposition. Gary, J. H., ed. Proceedings of the 17th Oil Shale Symposium; 1984 April 16-18; Golden, Co. Colorado School of Mines Press. 1984 August. $93-102$.

[161] Lee, I. C.; Sohn, H. Y. Intrinsic kinetics of low-temperature oxidation of oil shale kerogen. Fuel 65; 129-132; 1986. 
[162] Campbell, J. H.; Gallegos, G.; Gregg, M. Gas evolution during oil shale pyrolysis. 2. Kinetic and stoichiometric analysis. Fuel 59: 727-732; 1980.

[163] Campbe11, J. H.; Koskinas, G. J.; Gallegos, G. ; Gregg, M. Fuel 59: $718-726 ; 1980$.

[164] Anthony, D. B.; Howard, J. B. Coal devolatilization and hydrogasification. AIChE J. 22: 625-656; 1976.

[165] Nuttall, H. E.; Guo, T-M.; Schrader, S.; Thakur, D. S. Pyrolysis kinetics of several key world oil shales. ACS Symposium Series 230:269-300; 1983.

[166] Burnham, A. K.; Braun, R. L. General model of oil shale pyrolysis. Lawrence Livermore National Laboratory UCRL-89805, Rev. I, Preprint. April 1984.

[167] Fong, L; Floess, J. K. ; Chen, C-C.; Longwe11, J. P. ; Evans, L. B. Modeling of an oil shale fluidized-bed retorting process using ASPEN. Paper presented at the AIChE National meeting, Aug. 16-19, 1981. Detroit, MI.

[168] Phillips, T. T.; Odell, K. A.; Parkinson, W. J.; Rex, R. C.; Janka, J. C. ASPEN simulation of commercial HYTORT reactor configurations. Proceedings of the Eastern Oil Shale Symposium; 1984 Nov. 26-28; Lexington, KY. 1984; $321-330$. 
Table 1. Summary of consultations: oil shale

\section{Government}

Kentucky Energy Cabinet

Lawrence Livermore National Laboratory

Morgantown Energy Technology Center

United States Geological Survey: Denver; Reston, VA.

Western Research Institute

(formerly Laramie Energy Technology Center)

Industrial

Chevron

Exxon

Geokinetics

IGT

J\&A Associates

Marathon

Occidental
Paraho (Cathedral Bluffs, Colony, Shell)

Phillips

Texaco

TOSCO

Union Oil 
Table 2. Estimate of world-wide shale resources

$$
\left(10^{12} \mathrm{~L}\right)
$$

\begin{tabular}{|l|c|c|c|}
\hline $\begin{array}{c}\text { Grade of Shale } \\
\text { U.S. L/tonne } \\
(\text { gal/ton })\end{array}$ & $\begin{array}{c}20.9-41.7 \\
(5-10)\end{array}$ & $\begin{array}{c}41.7-104 \cdot 3 \\
(10-25)\end{array}$ & $\begin{array}{r}104.3-417 \cdot 3 \\
(25-100)\end{array}$ \\
\hline Africa & 53,550 & 9,520 & 476 \\
Asia & 70,210 & 13,090 & 654 \\
Oceania & 11,900 & 2,380 & 119 \\
(Incl. Australia) & 16,660 & 3,094 & 357 \\
Europe & 30,940 & 5,950 & 238 \\
North America & 24,990 & 4,760 & 2,010 \\
South America & 208,250 & 38,794 & \\
\hline
\end{tabular}


Table 3. Oil shale resources of the United States

$$
\left(10^{12} \mathrm{~L}\right)
$$

\begin{tabular}{|c|c|c|c|}
\hline $\begin{array}{l}\text { Grade of Shale } \\
\text { U.S. L/tonne } \\
\text { (gal/ton) }\end{array}$ & $\begin{array}{c}20.9-41.7 \\
(5-10)\end{array}$ & $\begin{array}{c}41 \cdot 7-104 \cdot 3 \\
(10-25)\end{array}$ & $\begin{array}{c}104 \cdot 3-417 \cdot 3 \\
(25-100)\end{array}$ \\
\hline $\begin{array}{c}\text { Green River } \\
\text { Formation }\end{array}$ & 476 & 333 & 143 \\
\hline $\begin{array}{l}\text { Devonian and } \\
\text { Mississippian } \\
\text { Shale (Central } \\
\text { and Eastern USA) }\end{array}$ & 238 & 119 & - \\
\hline $\begin{array}{l}\text { Marine Shale } \\
\text { (Alaska) }\end{array}$ & large & 24 & 30 \\
\hline Other deposits & 15,946 & 2648 & 60 \\
\hline Total & $16,660-30,940$ & $3,124-5,950$ & $232-357$ \\
\hline
\end{tabular}


Table 4. Estimate of abundance of eastern shales by hydroassay

\begin{tabular}{|l|c|c|}
\hline State & $\begin{array}{c}\text { Area suitable for } \\
\text { surface mining } \\
\text { (square km) }\end{array}$ & $\begin{array}{c}\text { Recoverable } \\
\text { resources } \\
(109)\end{array}$ \\
\hline Ohio & 2537 & 22,258 \\
Kentucky & 6861 & 30,208 \\
Tennessee & 3987 & 6,995 \\
Indiana & 4553 & 6,359 \\
Michigan & 777 & 636 \\
Alabama & 16,129 & 67,251 \\
\hline
\end{tabular}


Table 5. Organic and mineral constituents of eastern and western shales

\section{Organic}

Eastern

Western

Ultimate Analysis, (dry basis) wt \%

Organic Carbon
Hydrogen
Sulfur
Carbon Dioxide
Ash

Fischer Assay Analysis

Oil Yield, wt \%

Assay, gal/ton
13.7

1.6

4.7

0.5

78.3

4.6

10.3
13.6

2.1

0.5

15.9

66.8

\section{Minerals}

\section{Eastern}

\begin{tabular}{|c|c|}
\hline ao & (C \\
\hline Illite & (C1) \\
\hline Chlorite & (C1) \\
\hline (clay miner & is) \\
\hline Muscovite & (Si) \\
\hline Quartz & $(\mathrm{Si})$ \\
\hline Feldspar & $(\mathrm{Si})$ \\
\hline Zircon & $(\mathrm{Si})$ \\
\hline Tourmaline & ( Si \\
\hline Iron Oxides & \\
\hline Carbonates & \\
\hline yrite & \\
\hline patite & \\
\hline
\end{tabular}

\section{Western}

Dolomite

Calcite

Ankerite

Dawsonite

Magnesite

Mg Siderite

Nahcolite

Albite

K Feldspar

Analcime

Quartz

Orthoclase

Pyrite

Illite
(CO)

(CO)

(CO)

(CO)

(CO)

(CO)

(CO)

(Si)

(Si)

(Si)

(Si)

(Si)

(S)

(C1)

Key: Cl, clay; CO, carbonate; Si, silicate; O, oxide; S, sulfide; Ph, phosphate. 


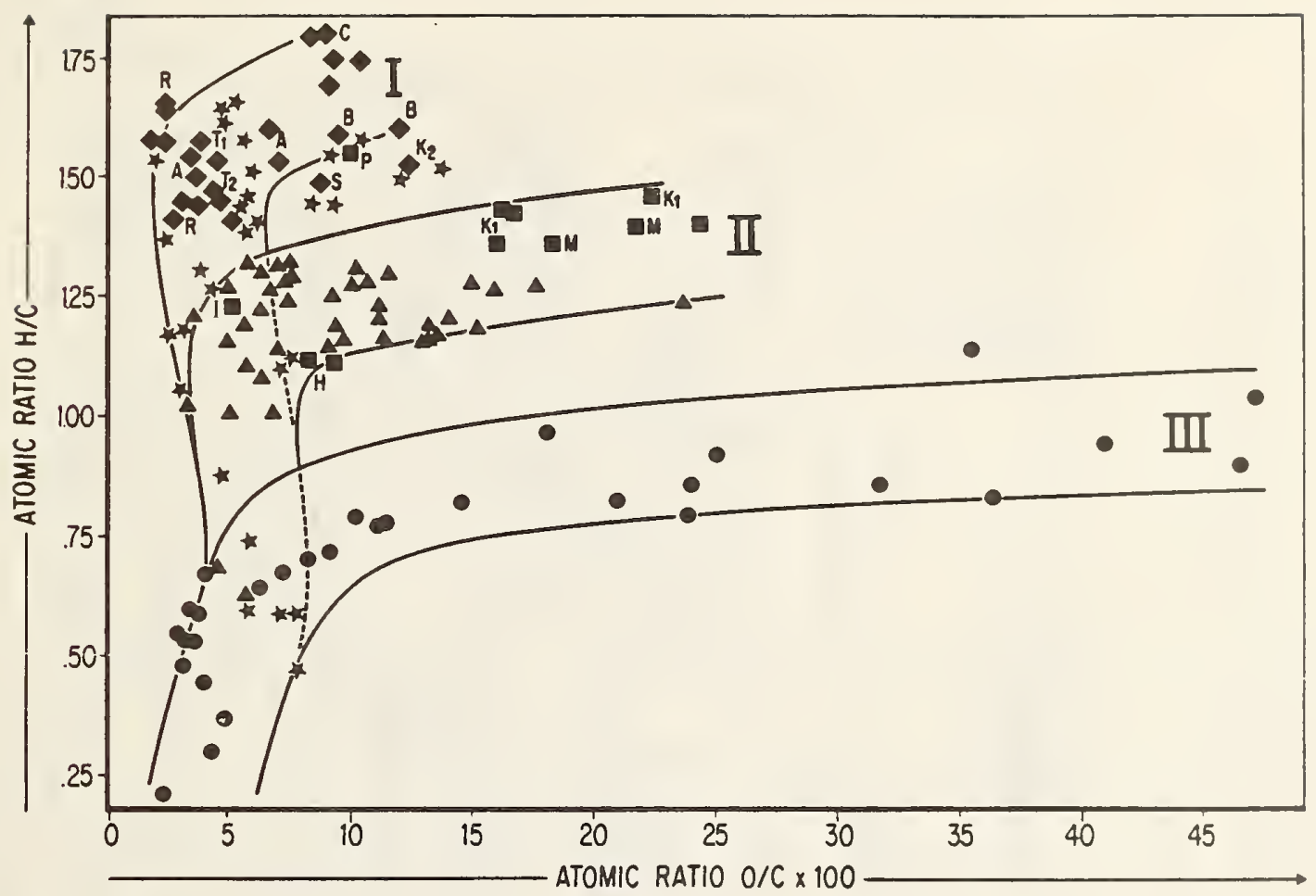

The organic constituents of the Green River shales ( $\star$ ) and the Toarcian shales ( $\Delta$ ) of the Paris Basin are typical kerogens of Types I and II, respectively. Other oil shales belong to either Type I ( $\diamond$ ) or II (⿴). Key: A, Autun boghead, Permian, France; B, Moscow boghead, Permian, USSR; C, Coorongite, recent, Australia; H. Marahunite, Tertiary, Brazil; I, Irati shales, Permian, Brazil; K, and $K_{2}$, Kukersite, Paleozoic, USSR; $M$, Messel shale, Eocene, W. Germany; R, Kerosene shale, Permian. Australia: S, Tasmanite, Permian, Australia; $T_{1}$, torbanite, Carboniferous, Scotland; and $T_{2}$, torbanite, Permian, Australia. The evolution path of humic coals (Type III) (৩) is show'n for comparison.

Figure 1. Van Krevelen diagram for oil shale kerogens.

Reprinted by permission of the American Chemical Society from Geochemistry and pyrolysis of oil shales by B. P. Tissot and M. Vandenbroucke in Geochemistry and Chemistry of Oil Shales, F. P. Miknis and J. F. McKay, eds., ACS Symposium Series 230, 1983. Copyright 1983 by American Chemical Society. 

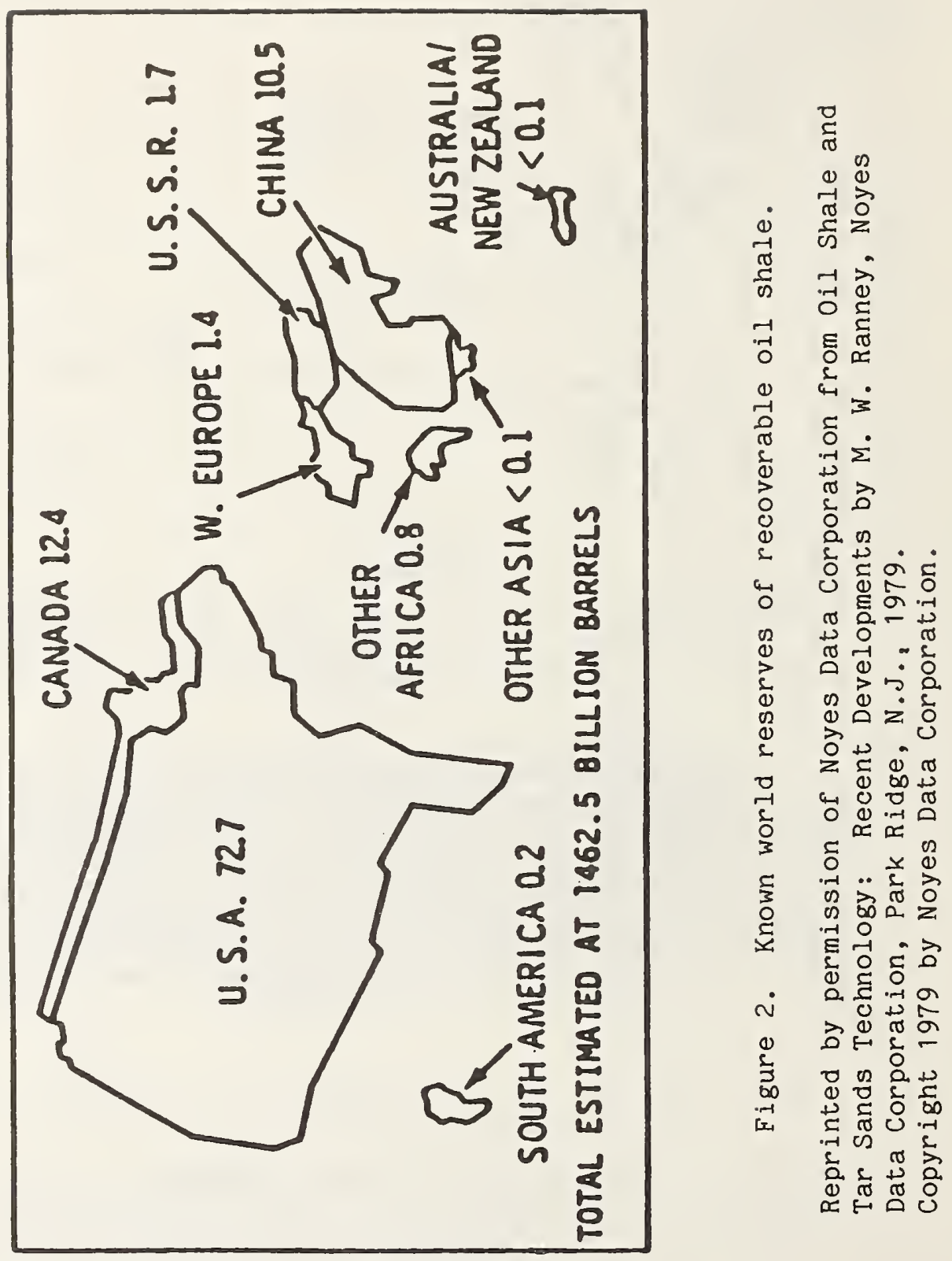


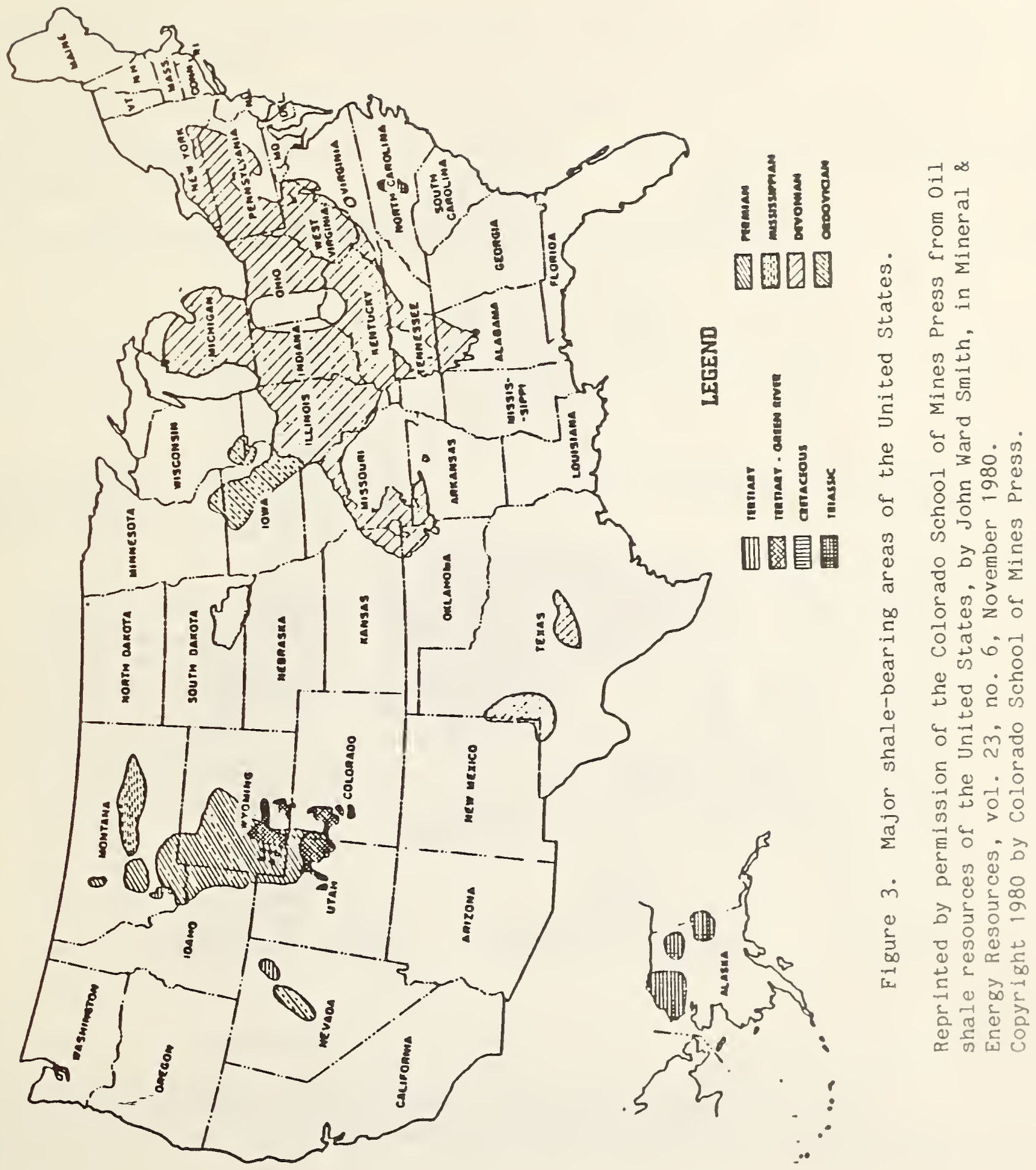




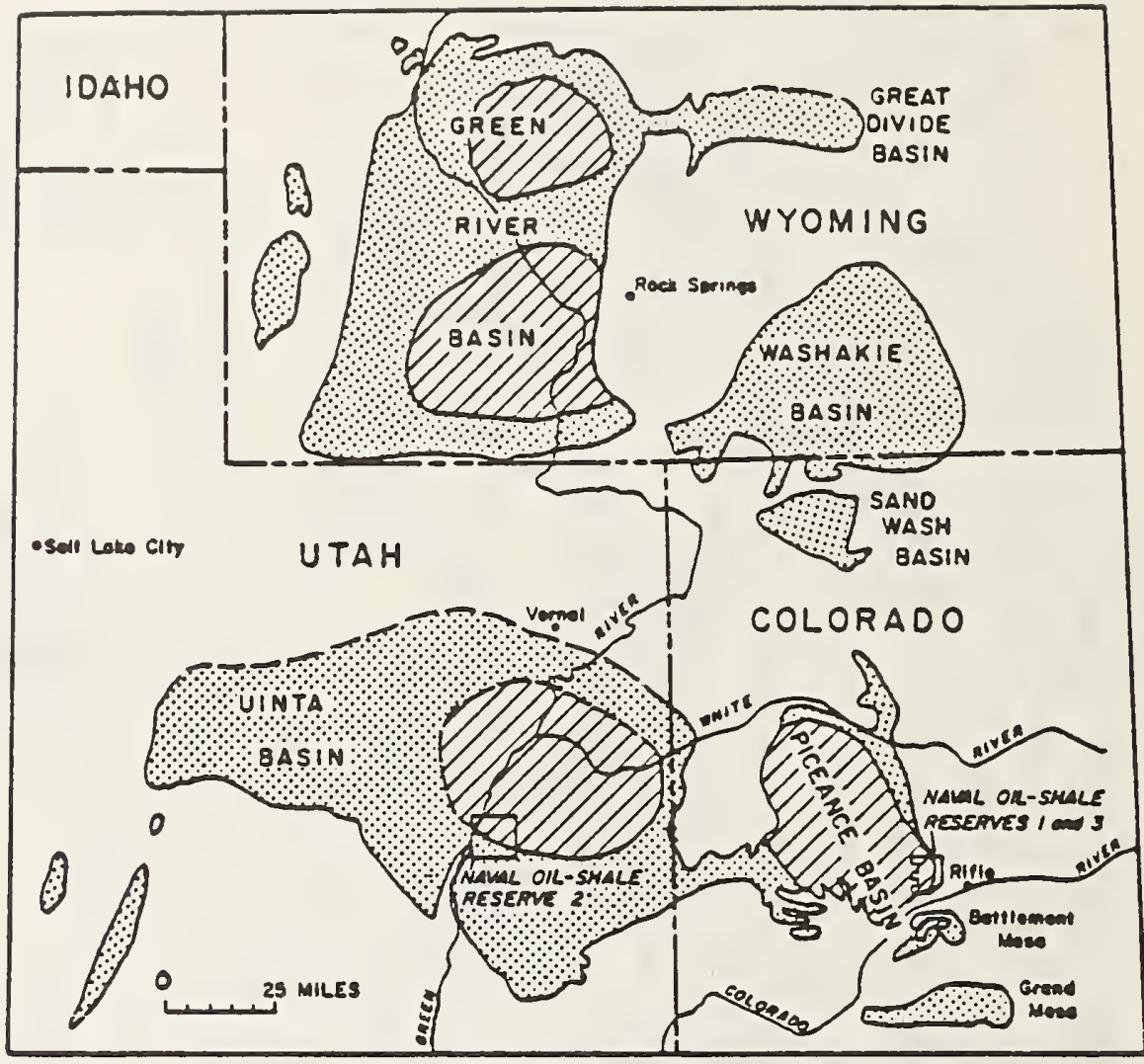

EXPLAMATION

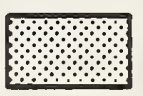

Ares underlein bs in Green River Formation in wien ine oil thale is unoppreised or low grecte.

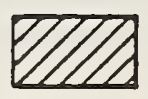

Ares underlatio by oil inde mere inse 10 feet inieh, which yiolds 25 pilleme or mere oil per tom of shata.

Figure 4. Green River shale deposits.

Reprinted by permission of the Colorado School of Mines Press from 0 il shale resources of the United States, by John Ward Smith, in Mineral \& Energy Resources, vol. 23, no. 6, November 1980. Copyright 1980 by Colorado School of Mines Press. 
4. TITLE AND SUBTITLE

Review of Needs for Thermophysical Property Data on Solid Feedstocks. II. Oil Shale

5. $A \cup T H O R(S)$

Jane E. Callanan

6. PERFORMING ORGANIZATION (If joint or other than NBS, see in structions)

7. ContracV/Grant No.

NATIONAL BUREAU OF STANDARDS

DEPARTMENT OF COMMERCE

WASHINGTON, D.C. 20234

9. SPONSORING ORGANIZATION NAME AND COMPLETE ADDRESS (Street, City, State, ZIP)

8. Type of Report \& Period Covered

10. SUPPLEMENTARY NOTES

Document describes a computer program; SF-185, FIPS Software Summary, is attached.

11. ABSTRACT (A 200-word or less factual summary of most significant information. If document includes a significant bibliography or literature survey, mention it here)

This report, a comprehensive survey concerning oil shale, is the second in a series dealing with needs, particularly for thermophysical properties, for solid fuels/feedstocks. This survey shows the need for experimental work on heat of combustion, heat of retorting, heat capacity/enthalpy, thermal conductivity, thermal expansion and heat of immersion for raw, spent and burnt shale, for kerogen and for the mineral matter found in shale. These studies should be preceded by agreement on the properties necessary for good characterization of the shale and on the methods of measuring these properties; the thermal properties measurements should be made on well-characterized samples. Standardized measurement techniques do not exist for thermal properties, with the possible exception of heat of combustion, and must be developed. Existing data must be evaluated and reliable data generated. Theoretical studies that will allow for modeling of thermal properties should proceed along with the experimental investigations to improve the ability to predict shale properties for process design. Recommendations for work appropriate to the National Bureau of Standards are included.

12. KEY WORDS (Six to twelve entries; alphabetical order; capitalize only proper names; and separate key words ty semicolons) enthalpy; heat capacity; heat of combustion; heat of immersion; heat of retorting; oil shale; review; solid fuels feedstocks; thermal conductivity; thermal expansion.

\section{AVAILABILITY}

$\mathrm{X}$ Unlimited

For Official Distribution. Do Not Release to NTIS

Order From Superintendent of Documents, U.S. Government Printing Office, Washington, D.C. 20402.

X Order From National Technical Information Service (NTIS), Springfield, VA. 22161

14. NO. OF

PRINTED PAGES

64

15. Price 


